\title{
Effects of prepartum dietary cation-anion difference and source of vitamin $D$ in dairy cows: Lactation performance and energy metabolism
}

\author{
N. Martinez, ${ }^{\star}$ R. M. Rodney,† E. Block,‡ L. L. Hernandez,§ C. D. Nelson, ${ }^{*}$ I. J. Lean,† and J. E. P. Santos $\#^{1}$ \\ *Department of Animal Sciences, University of Florida, Gainesville 32611 \\ †Scibus and University of Sydney, Camden, NSW 2570, Australia \\ †Arm \& Hammer Animal Nutrition, Princeton, NJ 08543 \\ $\S$ Department of Dairy Science, University of Wisconsin, Madison 53706 \\ \#D. H. Barron Reproductive and Perinatal Biology Research Program, University of Florida, Gainesville 32611
}

\begin{abstract}
The objectives of this experiment were to evaluate the effects of feeding diets with 2 dietary cation-anion difference (DCAD) levels and supplemented with either cholecalciferol $(\mathrm{CH})$ or calcidiol $(\mathrm{CA})$ during late gestation on lactation performance and energetic metabolism in dairy cows. The hypothesis was that combining a prepartum acidogenic diet with calcidiol supplementation would benefit peripartum Ca metabolism and, thus, improve energy metabolism and lactation performance compared with cows fed an alkalogenic diet or cholecalciferol. Holstein cows at $252 \mathrm{~d}$ of gestation were blocked by parity ( 28 nulliparous and 51 parous cows) and milk yield within parous cows, and randomly assigned to 1 of 4 treatments arranged as a $2 \times 2$ factorial, with 2 levels of DCAD (positive, +130 , and negative, $-130 \mathrm{mEq} / \mathrm{kg}$ ) and 2 sources of vitamin $\mathrm{D}, \mathrm{CH}$ or $\mathrm{CA}$, fed at $3 \mathrm{mg}$ per $11 \mathrm{~kg}$ of diet dry matter (DM). The resulting treatment combinations were positive DCAD with $\mathrm{CH}(\mathrm{PCH})$, positive DCAD with CA (PCA), negative DCAD with $\mathrm{CH}(\mathrm{NCH})$, or negative DCAD with CA (NCA), which were fed for the last $21 \mathrm{~d}$ of gestation. After calving, cows were fed the same lactation diet. Body weight and body condition were evaluated prepartum and for the first $49 \mathrm{~d}$ postpartum. Blood was sampled thrice weekly prepartum, and on d $0,1,2,3$, and every $3 \mathrm{~d}$ thereafter until $30 \mathrm{~d}$ postpartum for quantification of hormones and metabolites. Lactation performance was evaluated for the first $49 \mathrm{~d}$ postpartum. Feeding a diet with negative DCAD reduced DM intake in parous cows by 2.1 $\mathrm{kg} / \mathrm{d}$, but no effect was observed in nulliparous cows. The negative DCAD reduced concentrations of glucose (positive $=4.05$ vs. negative $=3.95 \mathrm{mM}$ ), insulin (positive $=0.57$ vs. negative $=0.45 \mathrm{ng} / \mathrm{mL}$ ), and insulin-like
\end{abstract}

Received August 25, 2017.

Accepted October 21, 2017

${ }^{1}$ Corresponding author: jepsantos@ufl.edu growth factor- 1 (positive $=110$ vs. negative $=95 \mathrm{ng} /$ $\mathrm{mL}$ ) prepartum. Treatments did not affect DM intake postpartum, but CA-supplemented cows tended to produce more colostrum $(\mathrm{PCH}=5.86, \mathrm{PCA}=7.68 \mathrm{NCH}$ $=6.21, \mathrm{NCA}=7.96 \pm 1.06 \mathrm{~kg})$ and produced more fatcorrected milk $(\mathrm{PCH}=37.0, \mathrm{PCA}=40.1 \mathrm{NCH}=37.5$, $\mathrm{NCA}=41.9 \pm 1.8 \mathrm{~kg}$ ) and milk components compared with CH-supplemented cows. Feeding the negative DCAD numerically increased yield of fat-corrected milk by $1.0 \mathrm{~kg} / \mathrm{d}$ in both nulliparous and $1.4 \mathrm{~kg} / \mathrm{d}$ in parous cows. Minor differences were observed in postpartum concentrations of hormones and metabolites linked to energy metabolism among treatments. Results from this experiment indicate that replacing $\mathrm{CH}$ with $\mathrm{CA}$ supplemented at $3 \mathrm{mg} / \mathrm{d}$ during the prepartum period improved postpartum lactation performance in dairy cows.

Key words: dairy cow, dietary cation-anion difference (DCAD), vitamin D, lactation

\section{INTRODUCTION}

Feeding acidogenic salts and products to manipulate the DCAD prepartum minimizes the decline in blood total calcium immediately after calving and reduces the incidence of milk fever in dairy cows (Ender et al., 1971; Block, 1984), although subclinical hypocalcemia remains prevalent in dairy herds (Reinhardt et al., 2011; Chapinal et al., 2012; Martinez et al., 2016). Subclinical hypocalcemia reduces DMI (Martinez et al., 2014), impairs energy metabolism (Chamberlin et al., 2013; Martinez et al., 2014), and suppresses immune function (Kehrli and Goff, 1989; Martinez et al., 2014). Cows induced to have subclinical hypocalcemia had signs of insulin resistance with reduced insulin concentrations and increased lipid mobilization despite increased blood glucose concentrations (Martinez et al., 2014). Furthermore, neutrophils from cows induced to have subclinical hypocalcemia had less cytosolic ionized $\mathrm{Ca}(\mathbf{i C a})$ and impaired phagocytic and killing activities 
(Martinez et al., 2014). Such changes in metabolism and immune function might explain the increased risk of diseases observed in cows that suffer from clinical and subclinical hypocalcemia (Seifi et al., 2011; Martinez et al., 2012). Therefore, the inability to maintain proper $\mathrm{Ca}$ homeostasis affects energy metabolism and immune function, which likely predisposes cows to diseases beyond milk fever, as observed by Curtis et al. (1983). Altering the DCAD of the prepartum diet to negative values improves peripartum $\mathrm{Ca}$ metabolism and increases milk yield in the first months of the subsequent lactation (Lean et al., 2014).

Cholecalciferol (vitamin $\mathrm{D}_{3}$ ) is one of the inactive forms of the vitamin and it is the product of UV light reacting with 7-dehydrocholesterol (Horst et al., 1994). Activation of vitamin $\mathrm{D}_{3}$ into 1,25-dihydoxyvitamin $\mathrm{D}_{3}$ or calcitriol occurs after 2 hydroxylation steps mediated by cytochrome P450 enzymes. The first hydroxylation occurs in the hepatic mitochondria and microsomes and is effected by vitamin D-25-hydroxylases (CYP2R1, CYP2J2, CYP27A1) forming 25-hydroxyvitamin $\mathrm{D}_{3}$ (calcidiol). The second hydroxylation takes place in the kidney and is carried out by the cytochrome P450 enzyme CYP27B1, also known as $1 \alpha$-hydroxylase. The $1 \alpha$-hydroxylase is tightly regulated by the coordinated actions of parathyroid hormone, calcitonin, and 1,25-dihydroxyvitamin $\mathrm{D}_{3}$ (Yoshida et al., 2001; Liu et al., 2006).

Most prepartum diets for dairy cows are supplemented with cholecalciferol, with a recommended dose of approximately $0.5 \mathrm{mg}$ for a $650-\mathrm{kg}$ cow (NRC, 2001). However, despite cholecalciferol supplementation and other prepartum dietary manipulations, the prevalence of subclinical hypocalcemia remains high during the first days of lactation (Reinhardt et al., 2011; Chapinal et al., 2012; Martinez et al., 2016). Recent findings demonstrated improvements in peripartum Ca metabolism in cows supplemented daily with $3 \mathrm{mg}$ of calcidiol per day, or 120,000 IU, combined with a diet containing a low DCAD (Wilkens et al., 2012). Cows fed a combination of $3 \mathrm{mg}$ of calcidiol and a diet with negative DCAD had greater mean plasma concentrations of iCa during the last days of gestation and first days of lactation compared with cows fed a diet with positive DCAD or not supplemented with calcidiol (Wilkens et al., 2012). Nevertheless, feeding $5.4 \mathrm{mg} / \mathrm{d}$ of calcidiol for the last $13 \mathrm{~d}$ prepartum seemed to cause more detrimental than beneficial effects on cows (Weiss et al., 2015). Thus, available data indicate that feeding more than $3 \mathrm{mg} / \mathrm{d}$ of calcidiol in the last 2 wk of gestation might be excessive and not benefit transition cows.

We hypothesized that supplementation with calcidiol is superior to supplementation with cholecalciferol in maintaining blood $\mathrm{Ca}$ concentrations during the peri- parturient period, which would benefit metabolism and lactation performance. We also hypothesized that the benefits of calcidiol are potentiated when fed with an acidogenic diet. The objectives of this experiment were to evaluate the effects of feeding diets with distinct DCAD and supplemented with 2 sources of vitamin D during late gestation on productive performance and energy metabolism in dairy cows.

\section{MATERIALS AND METHODS}

This article is one of a series of 3 companion papers (Martinez et al., 2018; Rodney et al., 2018). The University of Florida Institutional Animal Care and Use Committee approved all procedures involving cows in the experiment under the protocol number 201408331. Throughout the article, the vitamins fed will be referred to as cholecalciferol (CH) and calcidiol (CA), whereas measurements in blood plasma will be referred to as vitamin $\mathrm{D}_{3}, 25$-dihydroxyvitamin $\mathrm{D}_{3}$, and 1,25-dihydroxyvitamin $\mathrm{D}_{3}$.

\section{Cows and Housing}

The experiment was conducted in the University of Florida Dairy Unit from February to July 2014. Eighty pregnant dry Holstein cows (28 nulliparous and 52 parous) were enrolled in the experiment. Selection criteria included apparently healthy cows with no history of disease within $30 \mathrm{~d}$ before enrollment. Throughout the article, cows of lactation 0 at enrollment will be designated as nulliparous cows, whereas those enrolled in lactation $>0$ will be designated as parous cows. Nulliparous cows were enrolled in the experiment because of the scarce data on the effects of manipulating DCAD prepartum on postpartum lactation performance (Moore et al., 2000).

Body weight and BCS were (mean \pm SD), respectively, $600.9 \pm 34.5 \mathrm{~kg}$ and $3.58 \pm 0.25$ for nulliparous, and $738.6 \pm 88.6 \mathrm{~kg}$ and $3.55 \pm 0.41$ for parous cows on the day of enrollment, and lactation number for parous cows prepartum was (mean \pm SD) $1.96 \pm 0.98$. Cows at $252 \mathrm{~d}$ of gestation were moved to the experimental freestall barn to acclimate to the facilities and to individual feeding gates (Calan Broadbent feeding system, American Calan Inc., Northwood, NH). The first $3 \mathrm{~d}$ of feed intake were not considered for statistical analysis because cows were learning how to use the feeding gates. Therefore, measurements started at $255 \mathrm{~d}$ of gestation.

All prepartum cows were housed together in a freestall barn with sand-bedded stalls, and each cow was randomly assigned to an individual feeding gate. Immediately after calving, cows were moved to a second pen within the same barn and assigned to an individual 
feeding gate based on the sequence of calving. The experimental pens were equipped with 2 rows of fans (1 fan/6 linear meters), one facing the feed lane immediately above the feed bunk and the other immediately above the beds. Fans were equipped with low-pressure nozzles, and both fans and nozzles were activated once ambient temperature reached $18^{\circ} \mathrm{C}$.

\section{Feeding Management and Treatments}

Cows were fed once daily during the prepartum period, at $0730 \mathrm{~h}$, and twice daily, at 0730 and $1230 \mathrm{~h}$, in the postpartum period. The amounts of feed offered to individual cows were adjusted daily to result in at least $5 \%$ refusals, which were weighed once daily before the morning feeding. Description of diets is presented in Table 1.

The experiment followed a randomized complete block design with cow as the experimental unit. Weekly cohorts of prepartum cows at $252 \mathrm{~d}$ of gestation were blocked by parity ( 0 vs. $>0$ ) and previous lactation 305d milk yield (parous cows) and, within each block, assigned randomly to one of the 4 treatments. Treatments were arranged as a factorial with 2 levels of DCAD: positive $(+130 \mathrm{mEq} / \mathrm{kg})$ or negative $(-130 \mathrm{mEq} / \mathrm{kg})$ and 2 sources of vitamin $\mathrm{D}(\mathrm{CH}$ or $\mathrm{CA})$ that were fed at $3 \mathrm{mg}$ for each $11 \mathrm{~kg}$ of diet DM. We anticipated that the prepartum cows would consume, on average, $11 \mathrm{~kg}$ of $\mathrm{DM} / \mathrm{d}$ for the last $21 \mathrm{~d}$ of gestation, which would result in an intake of vitamin $\mathrm{D}$ of $3 \mathrm{mg} / \mathrm{d}$. Therefore, the 4 treatments were positive DCAD with $\mathrm{CH}(\mathbf{P C H}$; 7 nulliparous, 5 in lactation 1, 6 in lactation 2 , and 2 in lactation 3 or greater), positive DCAD with CA (PCA; 7 nulliparous, 6 in lactation 1, 4 in lactation 2, and 3 in lactation 3$)$, negative DCAD with $\mathrm{CH}(\mathbf{N C H}$; 7 nulliparous, 4 in lactation 1, 6 in lactation 2, and 3 in lactation 3 or greater), and negative DCAD with CA (NCA; 7 nulliparous, 4 in lactation 1, 5 in lactation 2, and 4 in lactation 3 or greater). Treatment diets were fed from 252 d of gestation to calving. Upon calving, cows were fed the same lactation ration for the first 49 DIM. All diets were fed as TMR.

\section{Ingredient Sampling, Chemical Analyses, and Calculation of DMI}

Forages and concentrate mixtures were collected weekly and dried at $55^{\circ} \mathrm{C}$; moisture loss was recorded and samples were stored for later analyses as monthly composites. Dried samples were ground to pass a 1-mm screen of a Wiley mill (Thomas Scientific, Swedesboro, $\mathrm{NJ})$, and analyzed for $\mathrm{DM}\left(105^{\circ} \mathrm{C}\right.$ for $\left.12 \mathrm{~h}\right)$. Dried samples were composited monthly and then analyzed for $\mathrm{OM}\left(512^{\circ} \mathrm{C}\right.$ for $\left.8 \mathrm{~h}\right)$, sequential analysis of NDF using a heat-stable $\alpha$-amylase (Van Soest et al., 1991), $\mathrm{N}$ using an automated quantitative combustion digestion method (Leco FP628, Leco Corp. St. Joseph, MI), starch after acid hydrolysis (Vidal et al., 2009), total fatty acids (Sukhija and Palmquist, 1988), and minerals by inductively coupled plasma mass spectrometry. The energy density of the diets was estimated using chemical analysis of dietary ingredients and calculated for 12.0 and $18.0 \mathrm{~kg}$ of DMI for the pre- and postpartum periods, respectively, using the NRC (2001) model (Table 1). Intake of DM for each cow was calculated daily for the first 42 DIM based on the DM content measured weekly at $105^{\circ} \mathrm{C}$ of the ingredients and the respective composition of diets.

\section{$B W$ and $B C S$}

Cows were weighed on the day of enrollment in the experiment and then once weekly prepartum, in the morning, during the last 3 wk of gestation. Body condition was scored on the day of enrollment and then once weekly by the same trained evaluator using a 1 to 5 scale (Ferguson et al., 1994) with increments of 0.25 units as depicted in the Elanco BCS chart (Elanco Animal Health, 2009). During the postpartum period, immediately after each milking, cows were weighed on a walk-though scale (AfiWeigh, S.A.E. Afikim, Israel) located on the exit lane of the milking parlor. Body condition was scored once weekly as described previously.

\section{Blood Samples}

Blood was collected 3 times per week from $265 \mathrm{~d}$ of gestation until calving, and postpartum at $0,1,2,3$, $6,9,12,15,18,21,24,27$, and $30 \mathrm{~d}$ postpartum by puncture of the coccygeal blood vessels into evacuated tubes (Vacutainer, Becton Dickinson, Franklin Lakes, NJ) containing no anticoagulant agents for serum separation or in tubes containing $\mathrm{K}_{2}$ EDTA for plasma separation. Samples were collected after the morning feeding between 0800 and $1000 \mathrm{~h}$. For the prepartum period, samples collected on d $-9,-6,-3$, and -1 relative to calving were used for assaying metabolites and hormones. Postpartum, all samples collected from 0 to 30 DIM were assayed for nonesterified fatty acids (NEFA), BHB, total protein, and glucose; samples collected every $3 \mathrm{~d}$ from 0 to 30 DIM were assayed for insulin IGF-1 and leptin; and samples collected every 6 d from 0 to 30 DIM were assayed for total cholesterol. Serum samples were allowed to clot and then placed on ice until processing. Samples with anticoagulant were 
placed in ice immediately upon collection and were processed within $4 \mathrm{~h}$ of collection. Tubes were centrifuged and serum and plasma were harvested and split into multiple aliquots and frozen at $-20^{\circ} \mathrm{C}$ until analyses.

\section{Blood Assays}

Plasma concentrations of NEFA (NEFA-C kit; Wako Diagnostics Inc., Richmond, VA; according to Johnson

Table 1. Dietary ingredients and nutrient composition of diets fed pre- and postpartum

\begin{tabular}{|c|c|c|c|c|c|}
\hline \multirow[b]{3}{*}{ Item } & \multicolumn{4}{|c|}{ Prepartum diet ${ }^{1}$} & \multirow{3}{*}{$\begin{array}{c}\text { Postpartum } \\
\text { diet }\end{array}$} \\
\hline & \multicolumn{2}{|c|}{ Positive DCAD } & \multicolumn{2}{|c|}{ Negative DCAD } & \\
\hline & Cholecalciferol & Calcidiol & Cholecalciferol & Calcidiol & \\
\hline \multicolumn{6}{|l|}{ Ingredients, $\%$ of DM } \\
\hline Corn silage & 61.80 & 61.80 & 61.80 & 61.80 & 25.8 \\
\hline Bermuda hay & 9.10 & 9.10 & 9.10 & 9.10 & 7.5 \\
\hline Brewer's grains, wet & - & - & - & - & 8.6 \\
\hline Corn grain, finely ground & - & - & - & - & 25.9 \\
\hline Citrus pulp & 9.10 & 9.10 & 9.10 & 9.10 & 5.2 \\
\hline Soybean hulls & - & - & - & - & 8.6 \\
\hline Whole cottonseed & 6.40 & 6.40 & 6.40 & 6.40 & 3.4 \\
\hline Soybean meal, solvent extract & - & - & 4.50 & 4.40 & 8.2 \\
\hline Soybean meal, cooker-processing ${ }^{2}$ & 11.18 & 11.08 & - & - & 3.3 \\
\hline Acidogenic supplement ${ }^{3}$ & - & - & 7.25 & 7.25 & - \\
\hline Cholecalciferol mixture ${ }^{4}$ & 0.08 & - & 0.08 & - & - \\
\hline Calcidiol mixture & - & 0.18 & - & 0.18 & - \\
\hline $\mathrm{MgO}+\mathrm{NaCl}$ & 0.54 & 0.54 & - & - & - \\
\hline Prepartum mineral ${ }^{6}$ & 1.80 & 1.80 & 1.80 & 1.80 & - \\
\hline Postpartum protein and mineral ${ }^{7}$ & 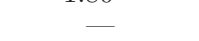 & 1 & - & - & 3.5 \\
\hline $\mathrm{DM}, \%$ & $55.4 \pm 1.0$ & $55.6 \pm 1.0$ & $55.4 \pm 1.0$ & $55.4 \pm 1.0$ & $69.5 \pm 0.6$ \\
\hline \multicolumn{6}{|l|}{ Nutrients, DM basis $( \pm \mathrm{SD})^{8}$} \\
\hline Net energy, ${ }^{9} \mathrm{Mcal} / \mathrm{kg}$ & 1.65 & 1.65 & 1.65 & 1.65 & 1.67 \\
\hline $\mathrm{OM}, \%$ & $94.0 \pm 0.4$ & $93.9 \pm 0.4$ & $94.2 \pm 0.4$ & $94.1 \pm 0.4$ & $94.0 \pm 0.1$ \\
\hline $\mathrm{CP}, \%$ & $13.5 \pm 0.3$ & $12.9 \pm 0.3$ & $13.5 \pm 0.3$ & $13.4 \pm 0.3$ & $15.7 \pm 0.6$ \\
\hline Starch, \% & $20.2 \pm 0.2$ & $20.1 \pm 0.2$ & $20.8 \pm 0.2$ & $20.9 \pm 0.2$ & $27.6 \pm 1.0$ \\
\hline $\mathrm{NFC}, 10 \%$ & $38.7 \pm 1.1$ & $38.1 \pm 1.1$ & $38.3 \pm 1.1$ & $38.5 \pm 1.1$ & $40.8 \pm 1.2$ \\
\hline NDF, $\%$ & $37.8 \pm 0.6$ & $39.0 \pm 0.6$ & $38.3 \pm 0.6$ & $38.2 \pm 0.6$ & $33.3 \pm 0.5$ \\
\hline NDF from forage, $\%$ & $30.8 \pm 0.7$ & $30.8 \pm 0.7$ & $30.8 \pm 0.7$ & $30.8 \pm 0.7$ & $15.8 \pm 0.4$ \\
\hline Fatty acids, $\%$ & $3.28 \pm 0.03$ & $3.33 \pm 0.03$ & $3.45 \pm 0.03$ & $3.37 \pm 0.03$ & $3.93 \pm 0.22$ \\
\hline $\mathrm{Ca}, \%$ & $0.61 \pm 0.08$ & $0.62 \pm 0.08$ & $0.54 \pm 0.08$ & $0.55 \pm 0.08$ & $0.59 \pm 0.03$ \\
\hline $\mathrm{P}, \%$ & $0.32 \pm 0.01$ & $0.31 \pm 0.01$ & $0.33 \pm 0.01$ & $0.32 \pm 0.01$ & $0.36 \pm 0.01$ \\
\hline $\mathrm{Mg}, \%$ & $0.39 \pm 0.02$ & $0.37 \pm 0.02$ & $0.38 \pm 0.02$ & $0.39 \pm 0.02$ & $0.27 \pm 0.01$ \\
\hline $\mathrm{K}, \%$ & $1.22 \pm 0.08$ & $1.19 \pm 0.08$ & $1.15 \pm 0.08$ & $1.15 \pm 0.08$ & $1.15 \pm 0.06$ \\
\hline $\mathrm{Na}, \%$ & $0.20 \pm 0.01$ & $0.20 \pm 0.01$ & $0.16 \pm 0.01$ & $0.16 \pm 0.01$ & $0.46 \pm 0.04$ \\
\hline $\mathrm{Cl}, \%$ & $0.54 \pm 0.04$ & $0.55 \pm 0.04$ & $0.94 \pm 0.04$ & $0.90 \pm 0.04$ & $0.30 \pm 0.01$ \\
\hline S, $\%$ & $0.17 \pm 0.004$ & $0.16 \pm 0.004$ & $0.37 \pm 0.004$ & $0.36 \pm 0.004$ & $0.18 \pm 0.01$ \\
\hline $\mathrm{DCAD},{ }^{11} \mathrm{mEq} / \mathrm{kg}$ & $145 \pm 11$ & $130 \pm 11$ & $-129 \pm 11$ & $-124 \pm 11$ & $293 \pm 28$ \\
\hline
\end{tabular}

${ }^{1}$ Prepartum cows starting at $252 \mathrm{~d}$ of gestation were fed diets with either a positive $(+130 \mathrm{mEq} / \mathrm{kg})$ or a negative $(-130 \mathrm{mEq} / \mathrm{kg}) \mathrm{DCAD}$. Within each DCAD diet, cows were fed either $3 \mathrm{mg}$ of cholecalciferol or $3 \mathrm{mg}$ of calcidiol.

${ }^{2}$ Amino Plus (cooker-processing soybean meal; Ag Processing Inc., Emmetsburg, IA).

${ }^{3}$ Bio-Chlor (a fermentation product containing dried condensed extracted glutamic acid fermentation product, dried condensed corn fermentation solubles, processed grain by-products, and magnesium chloride; Arm \& Hammer Animal Nutrition, Princeton, NJ).

${ }^{4}$ Rovimix D3 (a product containing $300 \mathrm{mg}$ of cholecalciferol per kg; Division of Animal Nutrition and Health, DSM Nutritional Products LLC, Parsippany, NJ).

${ }^{5} \mathrm{Hy}-\mathrm{D}$ (a product containing $153 \mathrm{mg}$ of calcidiol per kg; Division of Animal Nutrition and Health, DSM Nutritional Products LLC).

${ }^{6}$ Each kilogram contained (DM basis) $10.3 \% \mathrm{Ca}, 0.7 \% \mathrm{P}, 4.0 \% \mathrm{Mg}, 0.9 \% \mathrm{~K}, 0.25 \% \mathrm{~S}, 1.8 \% \mathrm{Na}, 2.7 \% \mathrm{Cl}, 1,750 \mathrm{mg}$ of $\mathrm{Zn}, 600 \mathrm{mg}$ of $\mathrm{Cu}, 1,090$ $\mathrm{mg}$ of Mn, $21 \mathrm{mg}$ of Se, $75 \mathrm{mg}$ of Co, $21 \mathrm{mg}$ of I, 260,000 IU of vitamin A, and 7,500 IU of vitamin E.

${ }^{7}$ A supplement containing $30 \%$ blood meal enriched with rumen-protected lysine and methionine (LysAAMet, Perdue Ag Solutions LLC, Salisbury, MD). Each kilogram contained (DM basis) $26.4 \% \mathrm{CP}, 5.1 \% \mathrm{Ca}, 1.6 \% \mathrm{P}, 4.1 \% \mathrm{Mg}, 6.8 \% \mathrm{~K}, 0.3 \% \mathrm{~S}, 10.7 \% \mathrm{Na}, 2.5 \% \mathrm{Cl}, 665 \mathrm{mg}$ of Zn, $230 \mathrm{mg}$ of $\mathrm{Cu}, 416 \mathrm{mg}$ of $\mathrm{Mn}, 7.2 \mathrm{mg}$ of Se, $24 \mathrm{mg}$ of Co, $13.6 \mathrm{mg}$ of I, 110,000 IU of vitamin A, 33,000 IU of cholecalciferol (0.825 mg), 1,100 IU of vitamin E, and $460 \mathrm{mg}$ of monensin (Rumensin 90, Elanco Animal Health, Eli Lilly and Co., Indianapolis, IN).

${ }^{8}$ Samples collected weekly and composited monthly for chemical analyses.

${ }^{9}$ Calculated based on the chemical analysis of dietary ingredients and using the NRC (2001) for a DMI of $12.0 \mathrm{~kg} / \mathrm{d}$ prepartum and $18 \mathrm{~kg} / \mathrm{d}$ postpartum.

${ }^{10}$ Calculated using the equation $\mathrm{DM}-[\mathrm{CP}+\mathrm{NDF}+$ fat + ash $-($ NDF insoluble protein $)]$.

${ }^{11}$ Calculated using the equation $[(\mathrm{mEq}$ of $\mathrm{Na}+\mathrm{mEq}$ of $\mathrm{K})-(\mathrm{mEq}$ of $\mathrm{Cl}+\mathrm{mEq}$ of $\mathrm{S})]$. 
and Peters, 1993) and BHB (Wako Autokit 3-HB; Wako Diagnostics Inc.) were analyzed using colorimetric enzymatic assays. The intra- and interassay coefficients of variation $(\mathbf{C V})$ were, respectively, 9.2 and $4.8 \%$ for NEFA, and 9.8 and $5.9 \%$ for BHB. Concentrations of glucose in plasma were determined by colorimetric continuous flow analysis (Autoanalyzer II, Seal Analytical, Southampton, UK) using a modification of the method described by Gochman and Schmitz (1972). Intra- and interassay CV were 2.6 and $3.8 \%$ for glucose. Concentrations of insulin (Bovine Insulin ELISA, Mercodia Inc., Uppsala, Sweden) and IGF-1 in plasma (R\&D Systems Inc., Minneapolis, MN) were analyzed by enzyme immunoassays. The intra- and interassay CV were, respectively, 3.1 and $4.7 \%$ for insulin, and 6.0 and $10.3 \%$ for IGF-1. Concentrations of leptin in plasma were analyzed by an ELISA at the Commonwealth Scientific and Industrial Research Organisation laboratory in Australia. Concentrations of total protein in serum were quantified using a digital clinical refractometer (TS Meter-D Automatic Digital Clinical Refractometer, Reichert Technologies, Buffalo, NY). Concentrations of cholesterol in serum were analyzed by an enzymatic colorimetric assay (Wako Cholesterol E; Wako Diagnostics Inc.). The intra- and interassay CV were 4.5 and $4.7 \%$, respectively. Details of assays of vitamin $\mathrm{D}$ metabolites in plasma and $\mathrm{iCa}$ in whole blood are presented in a companion paper (Rodney et al., 2018).

\section{Measurements of Colostrum, Milk, and Milk Components}

Cows were milked within the first $6 \mathrm{~h}$ after calving, colostrum yield was measured, and duplicate samples were collected and analyzed for concentrations of fat, true protein, lactose, SNF, TS, urea N, and SCC at the USDA Milk Market Administrator Laboratory (Lawrenceville, GA). In addition, colostrum samples were analyzed for IgG using a bovine IgG ELISA kit (ZMC cat. no. 0801198; ZeptoMetrix, Franklin, MA) according to manufacturer's instructions. Duplicate values were averaged for each cow.

Cows were milked twice daily at 0700 and $1900 \mathrm{~h}$, and yields of milk were recorded automatically (AfiFlo milk meters, S.A.E. Afikim, Israel) for the first 49 DIM. Samples of milk were collected once weekly in 2 sequential milkings, morning and afternoon, for measurements of concentrations of fat, true protein, lactose, and SCC at the Southeast Milk laboratory (Belleview, FL). Milk yield from each sampling was taken into account to calculate the final concentrations of milk components. Yields of milk corrected for $3.5 \%$ fat content and for energy, and the net energy (NE) content of milk were calculated according to NRC (2001) as follows: $3.5 \%$ $\mathrm{FCM}=0.4324 \times$ milk $\mathrm{kg}+(16.218 \times$ milk fat $\mathrm{kg}) ;$ $\mathrm{ECM}=[(0.3246 \times$ milk yield $)+(12.86 \times$ fat yield $)$ $+(7.04 \times$ protein yield $)] ; \mathrm{NE}=(0.0929 \times$ fat $\%)+$ $(0.0563 \times$ protein $\%)+(0.0395 \times$ lactose $\%)$.

\section{Measurement of Net Energy Balance}

Energy balance was calculated using daily caloric intake from DM intake and the energy content of the diets according to NRC (2001) using the $\mathrm{NE}_{\mathrm{L}}$ system. The needs for maintenance were calculated based on the formula of NRC (2001) and according to metabolic $\mathrm{BW}\left(0.08 \times \mathrm{BW}^{0.75}\right)$. Calories required for gestation for prepartum cows were estimated at $3.7 \mathrm{Mcal}$ of $\mathrm{NE}_{\mathrm{L}} / \mathrm{d}$ for a calf that would eventually be born with a BW of $43 \mathrm{~kg}$ (NRC, 2001). Calories secreted as milk were calculated according to yields of fat, protein, and lactose \{milk yield $\times[(0.0929 \times$ fat $\%)+(0.0563 \times$ protein $\%)$ $+(0.0395 \times$ lactose \%)] $\}$ based on NRC (2001). Daily values were averaged into weekly means for statistical analyses.

\section{Statistical Analysis}

The experiment followed a randomized complete block design with cow as the experimental unit. Prepartum cows at $252 \mathrm{~d}$ of gestation were blocked by parity $(0$ vs. $>0)$ and previous lactation 305-d milk (parous cows) and, within each block, assigned randomly to 1 of the 4 treatments. Sample size was calculated with the POWER procedure of SAS (version 9.4, SAS Institute Inc., Cary, NC) to detect differences in blood concentrations of total $\mathrm{Ca}$ and $\mathrm{iCa}$ and vitamin $\mathrm{D}$ metabolites described in Rodney et al. (2018). For those responses, only 5 cows per treatment were needed at $\alpha=0.05$ and $\beta=0.20$ if the standard deviations (SD) followed values observed previously (Martinez et al., 2012; Wilkens et al., 2012). Nevertheless, because our goal was also to determine whether dietary treatments affect production, we calculated the number of experimental units required to detect a minimum difference in milk yield of $2.6 \mathrm{~kg} / \mathrm{d}$ assuming an SD of $4 \mathrm{~kg}$. The sample size calculated assumed equal numbers of cows per main effects of DCAD or source of vitamin D at 39. A total of 40 cows per main effect was chosen to allow 20 cows per individual treatment.

Data were analyzed by ANOVA for the pre- and postpartum periods separately. Normality of residuals and homogeneity of variance were examined for each continuous dependent variable analyzed after fitting the final model. Responses that violated the assumptions of 
normality were subjected to power transformation according to the Box-Cox procedure (Box and Cox, 1964) using the PROC TRANSREG in SAS (SAS Institute Inc.). The least squares means and standard errors of the means were back transformed for presentation according to Jørgensen and Pedersen (1998).

The composition of colostrum was analyzed by using the MIXED procedure of SAS with mixed models that included the fixed effects of level of DCAD (positive vs. negative), source of vitamin $\mathrm{D}$ ( $\mathrm{CH}$ vs. $\mathrm{CA})$, parity (nulliparous vs. parous), the interactions between DCAD and vitamin D, DCAD and parity, vitamin D and parity, and DCAD and vitamin D and parity, and the random effect of block. The Kenward-Roger method was used to compute the approximate denominator degrees of freedom for the $F$ tests in the statistical models. When an interaction was significant, pairwise comparisons among treatments were performed after adjusting by the method of Tukey.

Data with repeated measures within experimental units were analyzed with mixed models using the MIXED procedure of SAS (SAS Institute Inc.). Models included the fixed effects of level of DCAD, source of vitamin $\mathrm{D}$, interaction between level of DCAD and source of vitamin D, parity, day of measurement, and interactions between DCAD and parity, vitamin D and parity, DCAD and day, vitamin D and day, parity and day, DCAD and vitamin D and parity, DCAD and vitamin D and day, DCAD and parity and day, vitamin $\mathrm{D}$ and parity and day, and DCAD and vitamin $\mathrm{D}$ and parity and day. Random effects included block and cow nested within level of DCAD and source of vitamin D. The covariance structure selected for each model was based on spacing of measurements and the smallest corrected Akaike's information criterion. The KenwardRoger method was used to compute the approximate denominator degrees of freedom for the $F$ tests in the statistical models. When an interaction was significant, pairwise comparisons among treatments were performed after adjusting by the method of Tukey. The models for $\mathrm{BW}$ and BCS included the values measured on the day of experiment enrollment as covariates.

Additional statistical analyses of postpartum DMI and yield of ECM were performed with the same models described above but including morbidity in the first 30 DIM (yes vs. no) and the interaction between morbidity and parity to determine whether changes in lactation performance caused by treatments were in part mediated by differences in morbidity in early lactation reported by Martinez et al. (2018).

Statistical significance was considered at $P \leq 0.05$, and tendency was considered at $0.05<P \leq 0.10$.

\section{RESULTS}

Twenty-eight nulliparous and 52 parous cows were enrolled in the experiment, but one parous cow in the $\mathrm{PCH}$ group was removed from data analyses because of diagnosis of lymphosarcoma during late gestation. Therefore, 79 cows were included in all statistical analyses. One PCA cow developed pneumonia because of aspiration of an oral $\mathrm{Ca}$ drench used to treat clinical hypocalcemia; she had to be euthanized, was removed prematurely from the experiment, and contributed data from enrollment to 2 DIM. The length of gestation $( \pm \mathrm{SD})$ was $275 \pm 4.4 \mathrm{~d}$, and days receiving the prepartum diets did not differ with treatment and averaged $22.7 \pm 5.3 \mathrm{~d}$. All cows in the experiment stayed a minimum of 2 wh in the prepartum diets and 1 cow remained a maximum of $34 \mathrm{~d}$.

Details of concentrations of vitamin D metabolites and minerals in blood are reported elsewhere (Rodney et al., 2018). Briefly, feeding $\mathrm{CH}$ increased $(P<0.001)$ the concentrations of vitamin $\mathrm{D}_{3}$ in plasma prepartum $(\mathrm{CH}=14.7$ vs. $\mathrm{CA}=1.1 \pm 0.6 \mathrm{ng} / \mathrm{mL})$ and postpartum $(\mathrm{CH}=5.6$ vs. $\mathrm{CA}=1.4 \pm 0.3 \mathrm{ng} / \mathrm{mL})$, whereas feeding CA increased $(P<0.001)$ the concentrations of 25-hydroxyvitamin $\mathrm{D}_{3}$ in plasma prepartum $(\mathrm{CH}=$ 59.7 vs. $\mathrm{CA}=237.0 \pm 6.8 \mathrm{ng} / \mathrm{mL}$ ) and postpartum $(\mathrm{CH}=58.5$ vs. $\mathrm{CA}=218.3 \pm 5.3 \mathrm{ng} / \mathrm{mL})$. Feeding the diet with negative DCAD reduced $(P<0.05)$ the concentrations of vitamin $\mathrm{D}_{3}$ and 25-hydroxyvitamin $\mathrm{D}_{3}$ pre- and postpartum compared with feeding the diet with positive DCAD (Rodney et al., 2018). Both negative DCAD and CA increased the concentrations of iCa prepartum $(\mathrm{PCH}=1.19, \mathrm{PCA}=1.25, \mathrm{NCH}=$ $1.22, \mathrm{NCA}=1.27 \mathrm{mM})$; however, at calving and on $\mathrm{d}$ 1 postpartum, concentrations of $\mathrm{iCa}$ increased $(P<$ 0.001) with feeding the diet with negative compared with positive DCAD (positive $=0.968$ vs. negative $=$ $1.110 \pm 0.008 \mathrm{mM}$ ), but no difference was observed for source of vitamin D.

\section{Prepartum Intake and Measures of Energy Status}

Dry matter intake prepartum was less $(P=0.04)$ in cows fed the negative DCAD than in those fed the positive DCAD (Table 2); however, an interaction $(P<0.01)$ between DCAD and parity was detected because the depression in intake caused by the negative DCAD diet was observed only in parous cows ( positive $=13.7$ vs. negative $=11.5 \pm 0.4 \mathrm{~kg} / \mathrm{d}$ ), not in nulliparous cows (positive $=11.0$ vs. negative $=$ $11.3 \pm 0.5 \mathrm{~kg} / \mathrm{d}$ ). Similarly, the caloric intake of cows consuming the negative DCAD treatment decreased 
Table 2. Effect of DCAD and source of vitamin D fed prepartum on measures of energy status in the last $21 \mathrm{~d}$ of gestation in Holstein cows ${ }^{1}$

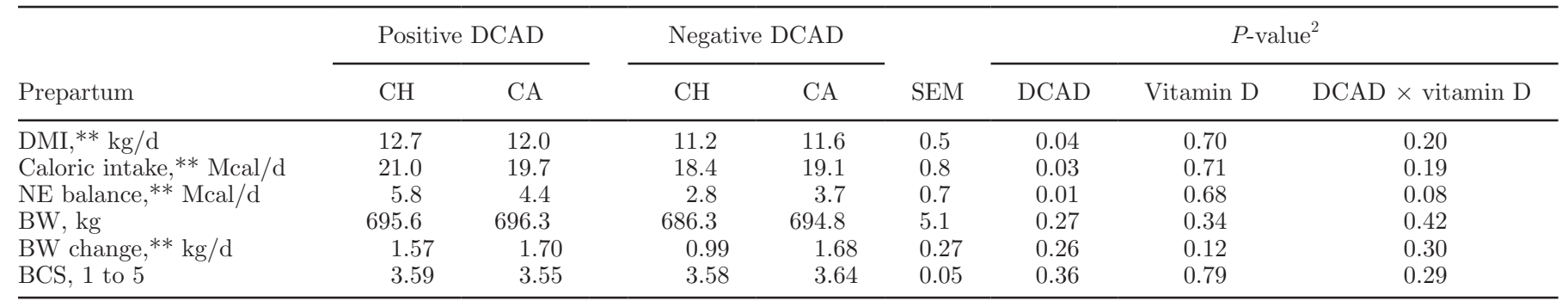

${ }^{1}$ Prepartum cows starting at $252 \mathrm{~d}$ of gestation were fed diets with either positive $(+130 \mathrm{mEq} / \mathrm{kg})$ or negative $(-130 \mathrm{mEq} / \mathrm{kg}) \mathrm{DCAD}$ and containing either $3 \mathrm{mg}$ of cholecalciferol $(\mathrm{CH})$ or $3 \mathrm{mg}$ of calcidiol $(\mathrm{CA})$.

${ }^{2} \mathrm{DCAD}=$ effect of DCAD (positive vs. negative); vitamin $\mathrm{D}=$ effect of source of vitamin $\mathrm{D}(\mathrm{CH}$ vs. $\mathrm{CA}) ; \mathrm{DCAD} \times$ vitamin $\mathrm{D}=$ interaction between DCAD and vitamin D.

**Interaction between DCAD and parity $(P<0.01)$.

$(P=0.03)$ because of an interaction $(P=0.01)$ between DCAD and parity (Figure $1 \mathrm{~A}$ and B). Dietary cation-anion difference did not affect caloric intake prepartum in nulliparous cows (positive $=18.2$ vs. negative $=18.6 \pm 0.8 \mathrm{Mcal}$ of $\left.\mathrm{NE}_{\mathrm{L}} / \mathrm{d}\right)$, but decreased $(P<0.001)$ that in parous cows (positive $=22.6$ vs. negative $=18.9 \pm 0.6 \mathrm{Mcal}$ of $\mathrm{NE}_{\mathrm{L}} / \mathrm{d}$ ). The changes in caloric intake resulted in differences in energy balance, which was less $(P<0.01)$ for parous cows fed the diet with negative DCAD compared with those fed the diet with positive DCAD (positive $=6.2$ vs. negative $=2.5 \pm 0.6$ Mcal of $\mathrm{NE}_{\mathrm{L}} / \mathrm{d}$ ), but no difference was observed for nulliparous cows (positive $=3.9$ vs. negative $=2.5 \pm 0.7 \mathrm{Mcal}$ of $\mathrm{NE}_{\mathrm{L}} / \mathrm{d}$ ). Despite the effects on intake of prepartum parous cows, the mean $\mathrm{NE}_{\mathrm{L}}$ balance remained positive until $2 \mathrm{~d}$ before calving in nulliparous or parous cows fed the diet with positive or the negative DCAD, and only on the day before calving did the mean $\mathrm{NE}_{\mathrm{L}}$ balance became negative for all cows fed either DCAD level. Source of vitamin $\mathrm{D}$ had no effect on prepartum DM, caloric intake, or $\mathrm{NE}_{\mathrm{L}}$ balance (Table 2).

Nulliparous and parous cows gained similar amounts of BW in the last $3 \mathrm{wk}$ of gestation, an average of $33.4 \pm 4.6 \mathrm{~kg}$ (Figure 2A and B). Nevertheless, an interaction $(P<0.01)$ between DCAD and parity was observed for daily BW change. Within parous cows, those fed the diet with positive DCAD gained more $(P<0.01)$ BW than those fed the diet with negative DCAD (positive $=1.96$ vs. negative $=0.93 \pm 0.24$ $\mathrm{kg} / \mathrm{d}$ ), whereas DCAD did not affect daily BW gain in nulliparous cows (positive $=1.31$ vs. negative $=1.74$ $\pm 0.32 \mathrm{~kg} / \mathrm{d}$ ). The changes in BW with DCAD were not replicated in changes in BCS. Treatments did not affect the mean BCS or the patterns of change in BCS prepartum in both nulliparous and parous cows (Table 2, Figure $1 \mathrm{C}$ and $\mathrm{D})$.

\section{Blood Concentrations of Metabolites Prepartum}

Concentrations of NEFA in plasma increased $(P<$ $0.01)$ as cows approached calving (Figure $3 \mathrm{~A})$. A tendency for an interaction $(P=0.06)$ between DCAD and source of vitamin $\mathrm{D}$ was detected for concentrations of NEFA prepartum because cows fed PCA tended $(P=$ 0.09 ) to have increased NEFA concentrations compared with cows receiving $\mathrm{PCH}$, whereas no difference in NEFA concentrations was observed between sources of vitamin $\mathrm{D}$ in cows fed the diet with negative DCAD (Table 3). Treatment did not affect concentrations of BHB, cholesterol, or total protein prepartum, and they remained relatively constant until the day before calving (Figure 3, panels B-D).

Concentrations of glucose increased $(P<0.01)$, whereas those of insulin, IGF-1, and leptin decreased $(P<0.05)$ as cows approached calving (Figure 4, panels A-D). Feeding the diet with negative DCAD reduced concentrations of glucose, insulin, and IGF-1 (Table 3). Nevertheless, interactions between DCAD and vitamin $\mathrm{D}$ were detected for insulin and IGF-1. For cows fed $\mathrm{CH}$, the diet with negative DCAD reduced $(P<0.01)$ the concentrations of insulin and IGF-1 in plasma compared with the diet with positive DCAD; however, no differences were observed for insulin and IGF-1 between cows fed PCA and NCA. Treatment did not influence concentrations of leptin prepartum (Table 3).

\section{Colostrum Yield and Composition}

Cows fed CA tended $(P=0.10)$ to produce $1.8 \mathrm{~kg}$ more colostrum than those fed $\mathrm{CH}(\mathrm{CH}=6.0$ vs. $\mathrm{CA}$ $=7.8 \pm 0.8 \mathrm{~kg})$ but DCAD had no effect on yield of colostrum (Table 4). As expected, parous cows produced more $(P<0.01)$ colostrum than nulliparous cows, 


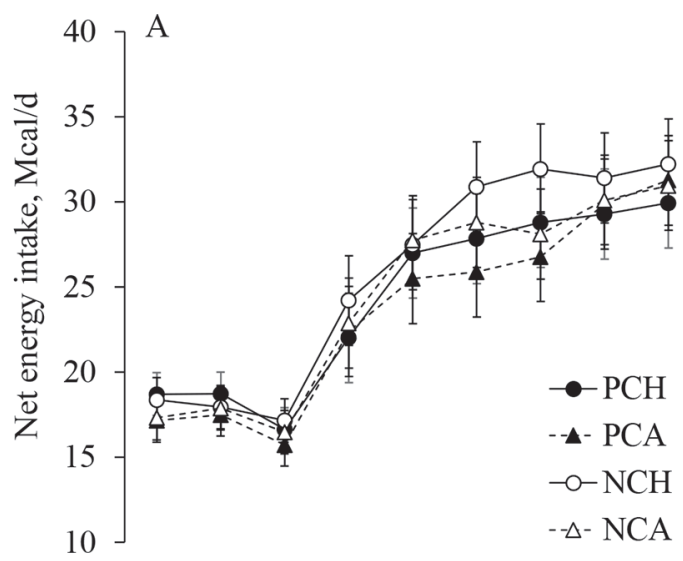

B
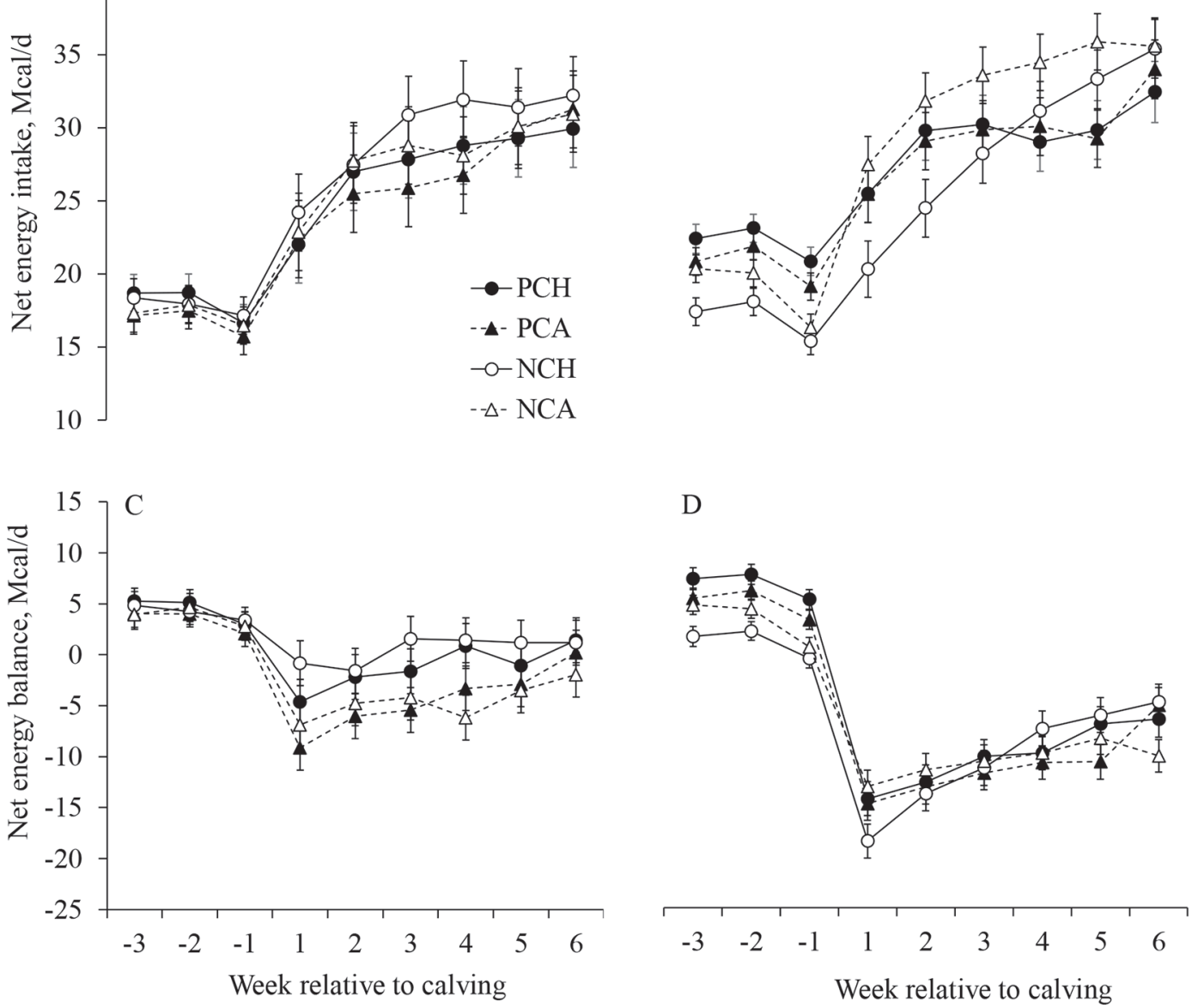

Figure 1. Net energy intake in (A) nulliparous and (B) parous cows and NE balance in (C) nulliparous and (D) parous cows fed prepartum diets with either positive $(\mathrm{P},+130 \mathrm{mEq} / \mathrm{kg})$ or negative $(\mathrm{N},-130 \mathrm{mEq} / \mathrm{kg})$ DCAD and containing either $3 \mathrm{mg}$ of cholecalciferol $(\mathrm{PCH}$ and $\mathrm{NCH}$, respectively) or $3 \mathrm{mg}$ of calcidiol (PCA and NCA, respectively). Panels A and B: Prepartum, effects of parity $(P=0.003)$, DCAD and parity $(P=0.01)$, vitamin D and parity $(P=0.43), \mathrm{DCAD}$ and vitamin $\mathrm{D}$ and parity $(P=0.33), \mathrm{DCAD}$ and parity and week $(P=0.27)$, vitamin $\mathrm{D}$ and parity and week $(P=0.52)$, and DCAD and vitamin D and parity and week $(P=0.66)$. Postpartum, effects of parity $(P=0.11)$, and interactions between DCAD and parity $(P=0.93)$, vitamin $\mathrm{D}$ and parity $(P=0.24), \mathrm{DCAD}$ and vitamin $\mathrm{D}$ and parity $(P=0.35), \mathrm{DCAD}$ and parity and week $(P=0.06)$, vitamin $\mathrm{D}$ and parity and week $(P=0.49)$, and DCAD and vitamin $\mathrm{D}$ and parity and week $(P=0.81)$. Panels $\mathrm{C}$ and D: Prepartum, effects of parity $(P=0.54)$, DCAD and parity $(P=0.005)$, vitamin $\mathrm{D}$ and parity $(P=0.52), \mathrm{DCAD}$ and vitamin D and parity $(P=0.22)$, DCAD and parity and week $(P=0.61)$, vitamin $\mathrm{D}$ and parity and week $(P=0.77)$, and DCAD and vitamin D and parity and week $(P=0.72)$. Postpartum, effects of parity $(P<0.001)$, DCAD and parity $(P=0.76)$, vitamin D and parity $(P=0.11)$, DCAD and vitamin D and parity $(P=0.55)$, DCAD and parity and week $(P=0.13)$, vitamin D and parity and week $(P=0.09)$, and DCAD and vitamin $\mathrm{D}$ and parity and week $(P=0.26)$. Error bars represent SEM.

which averaged 8.6 and $5.3 \pm 0.8 \mathrm{~kg}$, respectively. An interaction $(P=0.02)$ between DCAD and vitamin $\mathrm{D}$ was observed for fat content in colostrum. In cows fed the positive DCAD, CA tended $(P=0.07)$ to increase milk fat content compared with $\mathrm{CH}$, but within the diet with negative DCAD, those fed CA had numerically less $(P=0.11)$ fat content than cows fed $\mathrm{CH}$. Treatment did not affect yield of fat in colostrum, which averaged $0.34 \mathrm{~kg}$. An interaction $(P=0.04)$ between DCAD and vitamin D was observed for true protein content in colostrum because supplementing cows with CA increased $(P<0.01)$ true protein when fed the diet with positive DCAD but not that with negative
DCAD. Protein yield increased $(P=0.02)$ in cows fed $\mathrm{CA}$ compared with $\mathrm{CH}$, but it did not differ with level of DCAD. Lactose content in colostrum tended $(P=$ $0.07)$ to be greater for cows fed the positive compared with the negative DCAD, and it was greater $(P=$ 0.05 ) for cows fed $\mathrm{CH}$ than $\mathrm{CA}$, but yield of lactose was not affected by treatment. The concentrations of SNF and TS in colostrum increased $(P<0.05)$ with feeding $\mathrm{CA}$ in cows fed the positive DCAD diet but not the negative DCAD diet; however, yields of SNF and total solids in colostrum increased $(P<0.04)$ with $\mathrm{CA}$ compared with $\mathrm{CH}$ in the diets with positive and negative DCAD. 
Interactions $(P<0.05)$ between DCAD and vitamin $\mathrm{D}$ and parity were detected for concentrations of lactose, SNF, and TS in colostrum. In nulliparous cows, within those fed the positive DCAD, supplementing $\mathrm{CA}$ reduced $(P<0.05)$ lactose content $(\mathrm{PCH}=3.03$ vs. $\mathrm{PCA}=2.30 \pm 0.22 \%$ ), whereas within those fed the negative DCAD, supplementing $\mathrm{CA}$ increased lactose content $(\mathrm{NCH}=2.33$ vs. $\mathrm{NCA}=2.71 \pm 0.22 \%)$. On the other hand, no differences were observed for parous cows. For SNF and TS, the same responses were observed. In nulliparous cows, feeding $\mathrm{CA}$ within the positive DCAD increased $(P<0.05) \mathrm{SNF}(\mathrm{PCH}=15.6$ vs. $\mathrm{PCA}=21.8 \pm 1.4 \%)$, but the opposite response was observed for the diet with negative DCAD (NCH $=19.8$ vs. $\mathrm{NCA}=17.9 \pm 1.4 \%)$. On the other hand, no differences were observed within parous cows. Similarly, supplementing CA within the positive DCAD increased $(P<0.05)$ TS in colostrum of nulliparous cows $(\mathrm{PCH}$ $=20.6$ vs. $\mathrm{PCA}=28.5 \pm 1.6 \%$ ), but the opposite response was observed for the diet with negative DCAD $(\mathrm{NCH}=26.9$ vs. $\mathrm{NCA}=22.4 \pm 1.6 \%)$. No differences were observed for TS within parous cows.

An interaction $(P=0.001)$ between DCAD and vitamin D was observed for $\mathrm{NE}_{\mathrm{L}}$ content of colostrum. Supplementing CA increased the $\mathrm{NE}_{\mathrm{L}}$ content in colostrum of cows fed the positive DCAD, but the opposite response was observed when cows were fed the negative DCAD (Table 4). Nevertheless, calories secreted as colostrum increased $(P=0.04)$ when supplementing CA, and this response was observed in both levels of DCAD fed. The concentration of urea $\mathrm{N}$ in colostrum tended $(P=0.10)$ to increase with feeding CA compared with
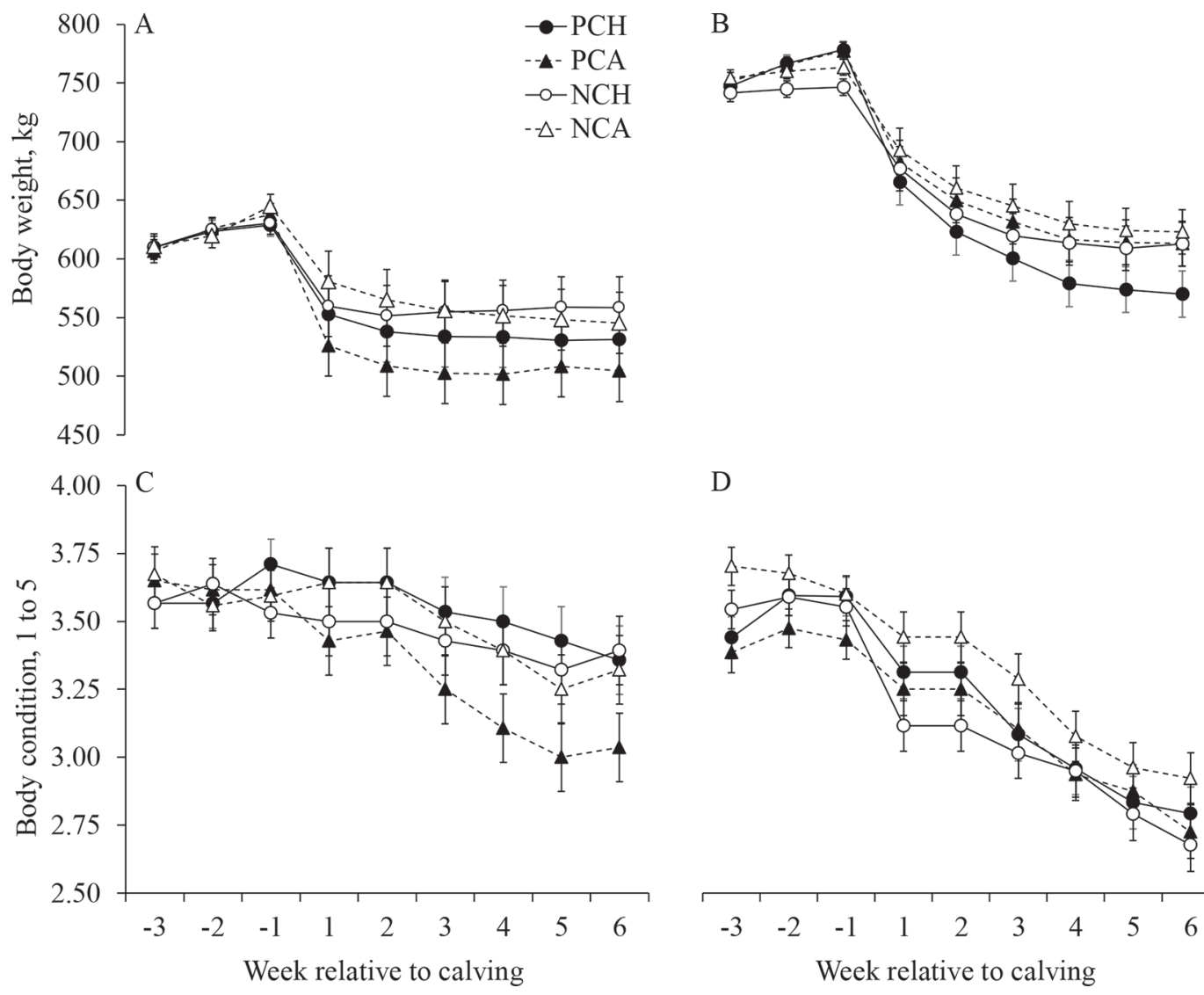

$\mathrm{D}$

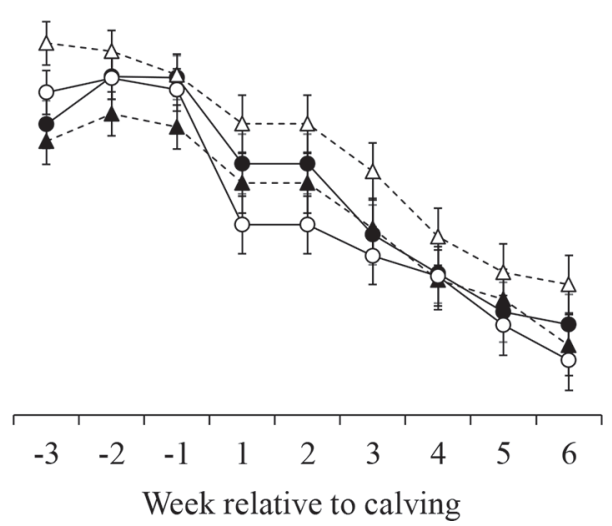

Figure 2. Body weight in (A) nulliparous and (B) parous cows and body condition in (C) nulliparous and (D) parous cows fed prepartum diets with either positive $(\mathrm{P},+130 \mathrm{mEq} / \mathrm{kg})$ or negative $(\mathrm{N},-130 \mathrm{mEq} / \mathrm{kg}) \mathrm{DCAD}$ and containing either $3 \mathrm{mg}$ of cholecalciferol $(\mathrm{PCH}$ and $\mathrm{NCH}$, respectively) or $3 \mathrm{mg}$ of calcidiol (PCA and NCA, respectively). Panels A and B: Prepartum, effects of parity $(P<0.001)$, and interactions between DCAD and parity $(P=0.19)$, vitamin $\mathrm{D}$ and parity $(P=0.64)$, DCAD and vitamin $\mathrm{D}$ and parity $(P=0.41)$, DCAD and parity and week $(P=0.07)$, vitamin D and parity and week $(P=0.35)$, and DCAD and vitamin D and parity and week $(P=0.63)$. Postpartum, effects of parity $(P<0.001)$, and interactions between DCAD and parity $(P=0.63)$, vitamin $\mathrm{D}$ and parity $(P=0.22), \mathrm{DCAD}$ and vitamin $\mathrm{D}$ and parity $(P=0.48)$, DCAD and parity and week $(P=0.84)$, vitamin D and parity and week $(P=0.29)$, and DCAD and vitamin D and parity and week $(P=0.81)$. Panels $\mathrm{C}$ and D: Prepartum, effects of parity $(P=0.31)$, and interactions between DCAD and parity $(P=0.12)$, vitamin D and parity $(P=0.82)$, DCAD and vitamin D and parity $(P=0.35)$, DCAD and parity and week $(P=0.70)$, vitamin $\mathrm{D}$ and parity and week $(P=$ $0.94)$, and DCAD and vitamin D and parity and week $(P=0.47)$. Postpartum, effects of parity $(P<0.001)$, and interactions between DCAD and parity $(P=0.71)$, vitamin $\mathrm{D}$ and parity $(P=0.05)$, DCAD and vitamin $\mathrm{D}$ and parity $(P=0.69)$, DCAD and parity and week $(P=0.98)$, vitamin $\mathrm{D}$ and parity and week $(P=0.38)$, and DCAD and vitamin D and parity and week $(P=0.23)$. Error bars represent SEM. 
Table 3. Effect of DCAD and source of vitamin D fed prepartum on concentrations of energy metabolites in the last $9 \mathrm{~d}$ of gestation in Holstein cows $^{1}$

\begin{tabular}{|c|c|c|c|c|c|c|c|c|}
\hline Prepartum & \multicolumn{2}{|c|}{ Positive DCAD } & \multicolumn{2}{|c|}{ Negative DCAD } & SEM & \multicolumn{3}{|c|}{$P$-value ${ }^{2}$} \\
\hline Nonesterified fatty acids, $† \mathrm{~m} M$ & 0.19 & 0.24 & 0.24 & 0.22 & 0.02 & 0.35 & 0.54 & 0.06 \\
\hline Cholesterol, mg/dL & 72.0 & 76.2 & 80.0 & 82.4 & 4.5 & 0.05 & 0.36 & 0.80 \\
\hline Total protein, mg/dL & 6.22 & 6.21 & 6.11 & 6.09 & 0.09 & 0.19 & 0.89 & 0.92 \\
\hline Glucose, $\mathrm{m} M$ & 4.10 & 4.05 & 3.90 & 3.99 & 0.06 & 0.03 & 0.72 & 0.26 \\
\hline Leptin, $\mathrm{ng} / \mathrm{mL}$ & 3.68 & 3.64 & 3.07 & 3.98 & 0.42 & 0.61 & 0.17 & 0.14 \\
\hline
\end{tabular}

${ }^{1}$ Prepartum cows starting at $252 \mathrm{~d}$ of gestation were fed diets with either positive $(+130 \mathrm{mEq} / \mathrm{kg})$ or negative $(-130 \mathrm{mEq} / \mathrm{kg}) \mathrm{DCAD}$ and containing either $3 \mathrm{mg}$ of cholecalciferol $(\mathrm{CH})$ or $3 \mathrm{mg}$ of calcidiol $(\mathrm{CA})$. Blood sampled on $\mathrm{d}-9,-6,-3$ and -1 relative to calving.

${ }^{2} \mathrm{DCAD}=$ effect of $\mathrm{DCAD}$ (positive vs. negative); vitamin $\mathrm{D}=$ effect of source of vitamin $\mathrm{D}(\mathrm{CH}$ vs. $\mathrm{CA}) ; \mathrm{DCAD} \times$ vitamin $\mathrm{D}=$ interaction between DCAD and vitamin D.

$\dagger$ Interaction between source of vitamin $\mathrm{D}$ and parity $(P=0.08)$.

$\mathrm{CH}$, but no effect of DCAD was observed. Cows fed CA produced colostrum with greater $(P=0.005)$ IgG content than those fed $\mathrm{CH}$, but DCAD had no effect on colostrum IgG concentration. Treatments did not affect the SCS in colostrum.
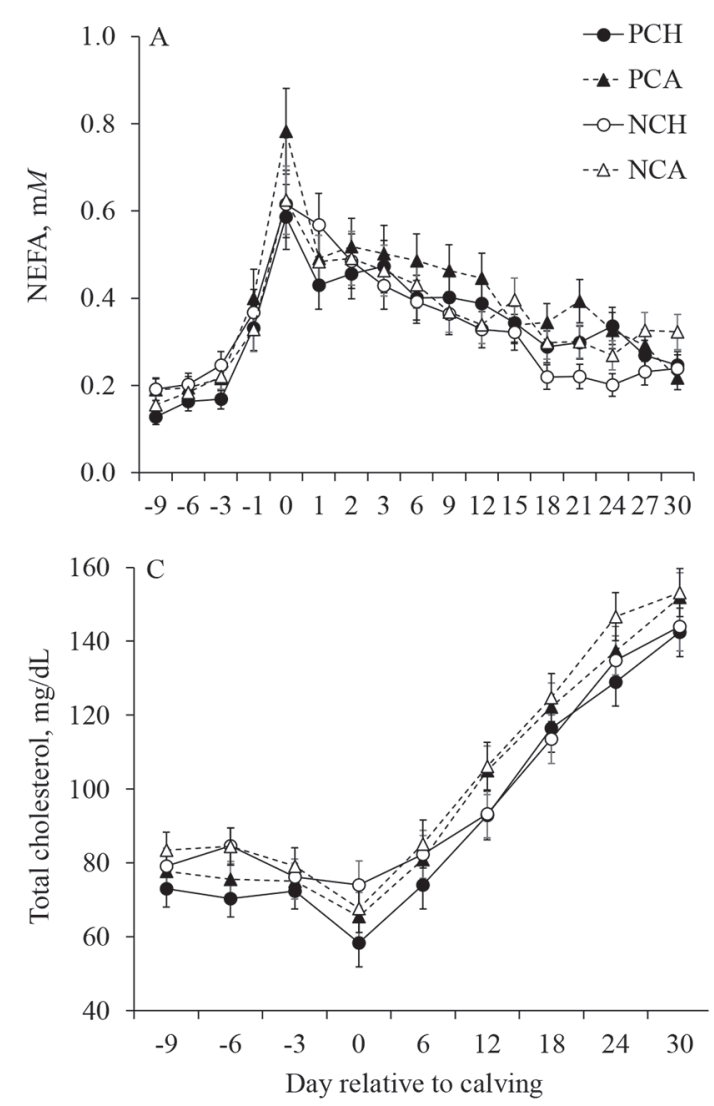

\section{Lactation Performance}

Supplementing diets with CA improved $(P<0.05)$ yields of milk, $3.5 \%$ FCM, and ECM in nulliparous and parous cows (Table 5), and the differences in production
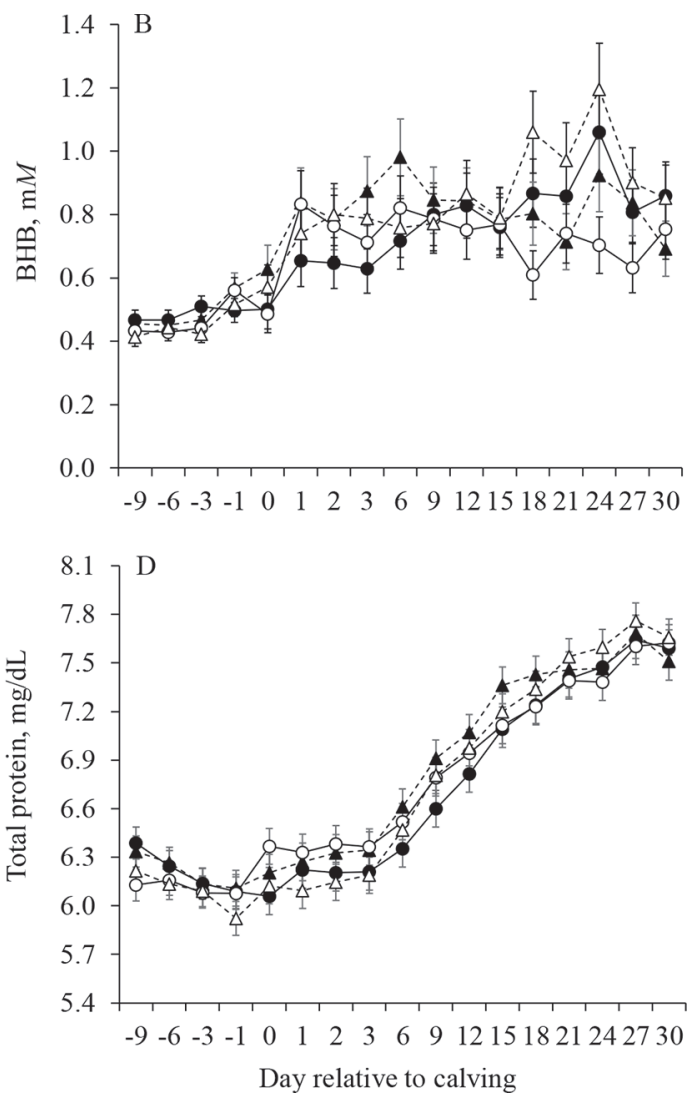

Figure 3. Concentrations of (A) nonesterified fatty acids (NEFA) and (B) BHB in plasma, and (C) total cholesterol and (D) protein in serum of cows fed prepartum diets containing either positive $(\mathrm{P},+130 \mathrm{mEq} / \mathrm{kg})$ or negative $(\mathrm{N},-130 \mathrm{mEq} / \mathrm{kg})$ DCAD and supplemented with either $3 \mathrm{mg}$ of cholecalciferol (PCH and $\mathrm{NCH}$, respectively) or $3 \mathrm{mg}$ of calcidiol (PCA and NCA, respectively). Error bars represent SEM. 
were observed throughout the 49-d experiment (Figure 5, panels $\mathrm{A}$ and $\mathrm{B}$ ). Cows supplemented with $\mathrm{CA}$ produced approximately $3.70 \mathrm{~kg} / \mathrm{d}$ more $(P=0.008)$ milk than those supplemented with $\mathrm{CH}$. In addition, cows fed CA tended $(P<0.07)$ to have increased yields of fat and true protein and increased $(P=0.03)$ yield of lactose because of changes in milk yield, not because of changes in content of those compounds in milk. Feeding a diet with negative compared with positive DCAD increased $(P=0.05)$ the content of fat in milk, but DCAD only numerically increased yields of $3.5 \% \mathrm{FCM}$ (positive $=38.5$ vs. negative $=39.7 \pm 1.2 \mathrm{~kg} / \mathrm{d}$ ) and ECM (positive $=37.1$ vs. negative $=38.3 \pm 1.2 \mathrm{~kg} / \mathrm{d}$ ) by $1.2 \mathrm{~kg} / \mathrm{d}$. Treatments did not affect the SCS in milk.

Additional analyses of DMI and production included morbidity described by Martinez et al. (2018) in the statistical models. Cows with morbidity produced 6.3 $\mathrm{kg} / \mathrm{d}$ less $(P<0.001)$ milk than healthy cows $(34.2$ vs. $40.5 \pm 1.1 \mathrm{~kg} / \mathrm{d})$ and the differences were observed in both nulliparous (28.5 vs. $33.7 \pm 1.8 \mathrm{~kg} / \mathrm{d}$ ) and parous cows (40.0 vs. $47.2 \pm 1.6 \mathrm{~kg} / \mathrm{d})$.
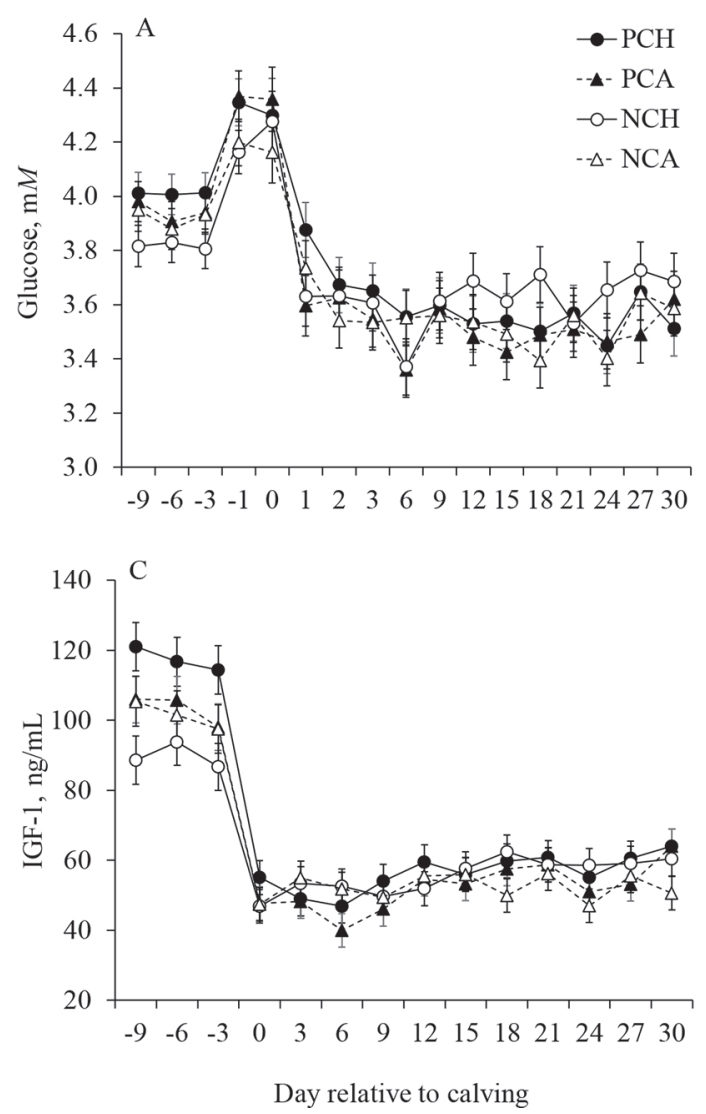

\section{Postpartum DMI and Measures of Energy Status}

Treatments did not affect the intakes of DM or calories during the first $42 \mathrm{DIM}$ (Table 6). As expected, cows with morbidity consumed $2.7 \mathrm{~kg} / \mathrm{d}$ less $(P=0.003) \mathrm{DM}$ than healthy cows $(16.0$ vs. $18.7 \pm 0.6 \mathrm{~kg} / \mathrm{d})$, and the detrimental effect of morbidity on DMI was observed in both nulliparous (15.8 vs. $17.9 \pm 0.9 \mathrm{~kg} / \mathrm{d}$ ) and parous cows (15.9 vs. $19.7 \pm 0.7 \mathrm{~kg} / \mathrm{d})$.

An interaction $(P<0.05)$ between source of vitamin $\mathrm{D}$ and parity was detected for efficiency of feed conversion into ECM (Figure 5, panels $\mathrm{C}$ and D). Within nulliparous cows, feeding CA increased $(P=0.04)$ feed efficiency $(\mathrm{CH}=1.69$ vs. $\mathrm{CA}=2.05 \pm 0.12)$, but no effect was observed for parous cows $(\mathrm{CH}=2.62$ vs. $\mathrm{CA}$ $=2.51 \pm 0.12)$. Feeding the diet with negative DCAD increased $(P=0.02)$ the NE concentration in milk, and the increment with the negative DCAD tended $(P$ $=0.09)$ to be greater in cows receiving $\mathrm{CA}$ than $\mathrm{CH}$ (Table 6). Nevertheless, DCAD did not influence the amount of NE secreted as milk. The increased milk
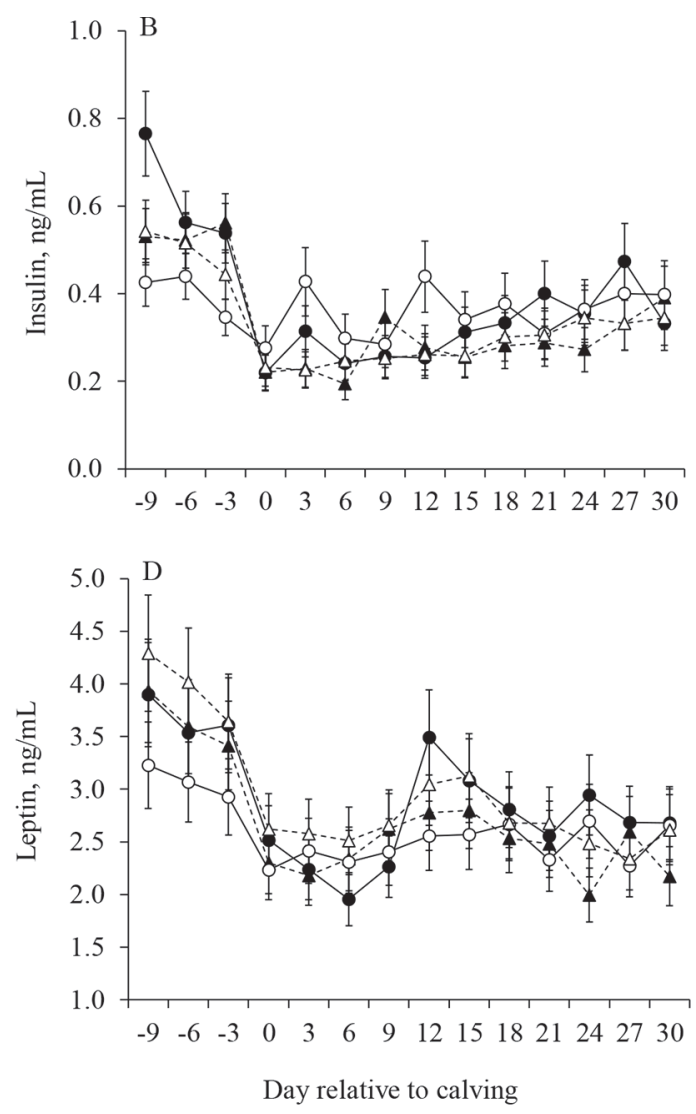

Figure 4. Concentrations of (A) glucose $(\mathrm{m} M)$, (B) insulin $(\mathrm{ng} / \mathrm{mL})$, (C) IGF-1 (ng/mL), and (D) leptin in plasma of cows fed prepartum diets containing either positive $(\mathrm{P},+130 \mathrm{mEq} / \mathrm{kg})$ or negative $(\mathrm{N},-130 \mathrm{mEq} / \mathrm{kg})$ DCAD and supplemented with either $3 \mathrm{mg}$ of cholecalciferol (PCH and $\mathrm{NCH}$, respectively) or $3 \mathrm{mg}$ of calcidiol (PCA and NCA, respectively). Error bars represent SEM. 
Table 4. Effect of DCAD and source of vitamin D fed prepartum on colostrum yield and composition in Holstein cows ${ }^{1}$

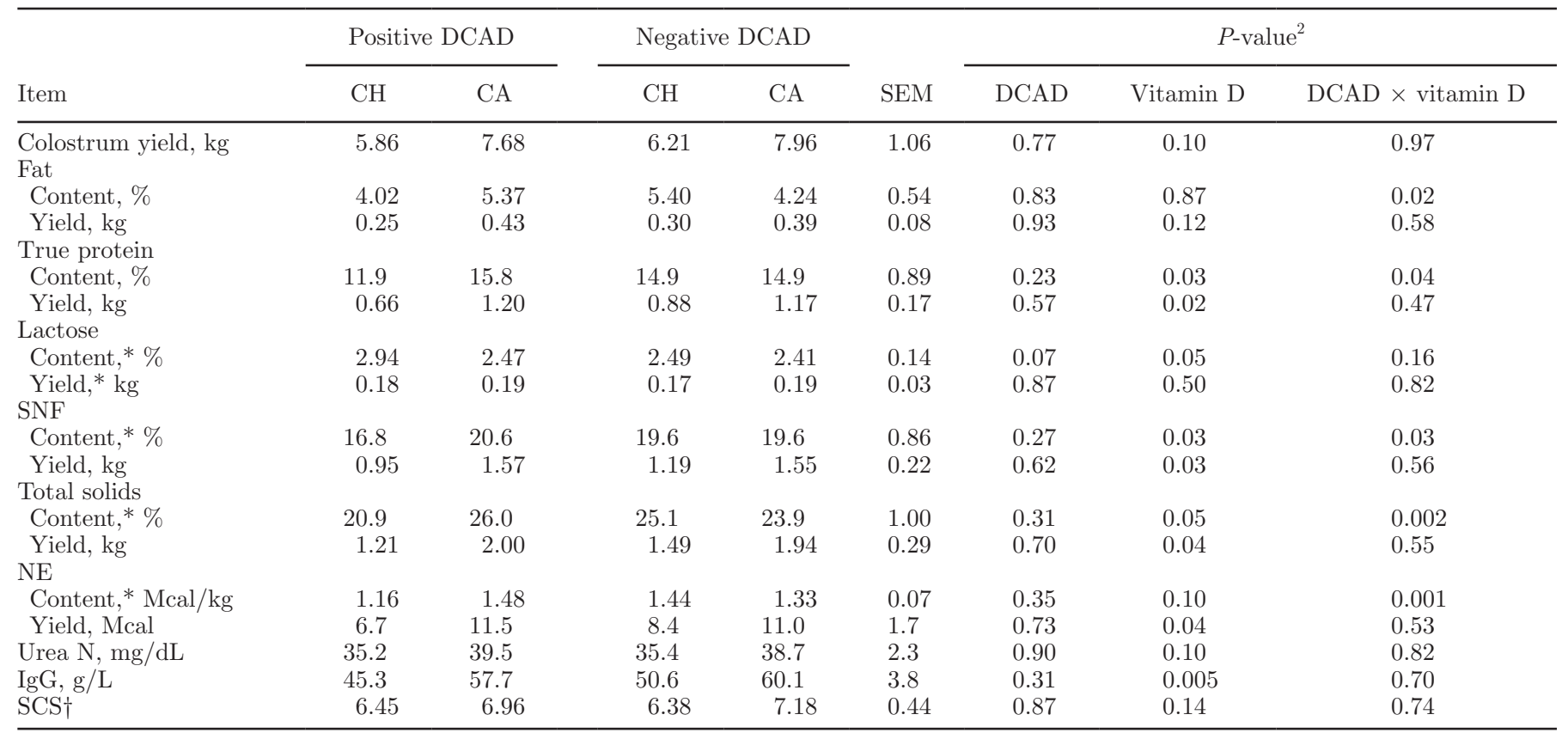

${ }^{1}$ Prepartum cows starting at $252 \mathrm{~d}$ of gestation were fed diets with either positive $(+130 \mathrm{mEq} / \mathrm{kg})$ or negative $(-130 \mathrm{mEq} / \mathrm{kg}) \mathrm{DCAD}$ and containing either $3 \mathrm{mg}$ of cholecalciferol $(\mathrm{CH})$ or $3 \mathrm{mg}$ of calcidiol $(\mathrm{CA})$.

${ }^{2} \mathrm{DCAD}=$ effect of DCAD (positive vs. negative); vitamin $\mathrm{D}=$ effect of source of vitamin $\mathrm{D}(\mathrm{CH}$ vs. CA); DCAD $\times$ vitamin $\mathrm{D}=$ interaction between DCAD and vitamin D.

*Interaction between DCAD, vitamin $\mathrm{D}$, and parity $(P<0.05)$.

$\dagger$ Interaction between DCAD and parity $(P=0.09)$.

yield in cows fed CA resulted in greater $(P=0.03)$ daily NE secretion as milk compared with cows fed $\mathrm{CH}$ (Table 6). As expected, the onset of lactation induced a period of negative NE balance; the nadir was observed in the first week of lactation and averaged $-5.4 \pm 1.1$ and $-15.0 \pm 0.8 \mathrm{Mcal} / \mathrm{d}$ in nulliparous and parous cows, respectively (Figure 1, panels $\mathrm{C}$ and D). Altering the prepartum $\mathrm{DCAD}$ did not affect $\mathrm{NE}_{\mathrm{L}}$ balance, but the increased caloric secretion in milk with feeding CA resulted in smaller $(P=0.03) \mathrm{NE}_{\mathrm{L}}$ balances in nulliparous and parous cows (Table 6, Figure 1, panels $\mathrm{C}$ and D). Nulliparous returned to positive $\mathrm{NE}_{\mathrm{L}}$ balance by wk

Table 5. Effect of DCAD and source of vitamin D fed prepartum on lactation performance in the first 49 d postpartum in Holstein cows ${ }^{1}$

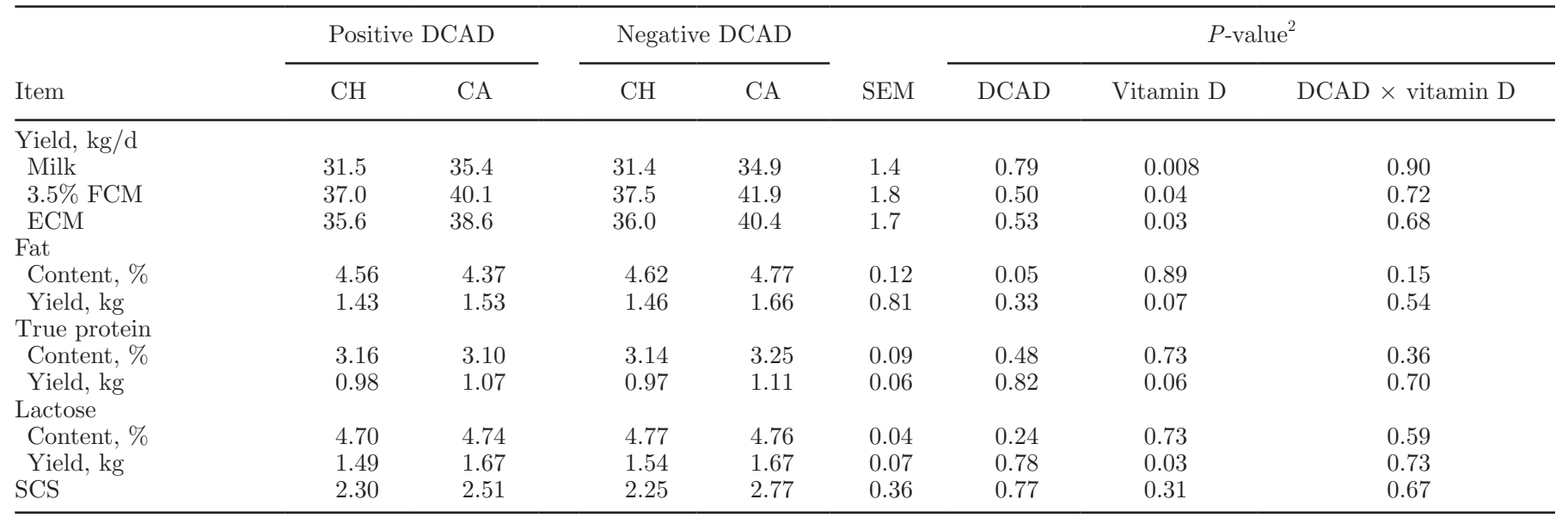

${ }^{1}$ Prepartum cows starting at $252 \mathrm{~d}$ of gestation were fed diets with either positive $(+130 \mathrm{mEq} / \mathrm{kg})$ or negative $(-130 \mathrm{mEq} / \mathrm{kg}) \mathrm{DCAD}$ and containing either $3 \mathrm{mg}$ of cholecalciferol $(\mathrm{CH})$ or $3 \mathrm{mg}$ of calcidiol $(\mathrm{CA})$.

${ }^{2} \mathrm{DCAD}=$ effect of $\mathrm{DCAD}$ (positive vs. negative); vitamin $\mathrm{D}=$ effect of source of vitamin $\mathrm{D}(\mathrm{CH}$ vs. $\mathrm{CA}) ; \mathrm{DCAD} \times$ vitamin $\mathrm{D}=$ interaction between DCAD and vitamin $\mathrm{D}$. 
6 postpartum, whereas parous cows remained in negative energy status at $6 \mathrm{wk}$ postpartum. No interactions between parity and DCAD or vitamin $\mathrm{D}$ were observed for $\mathrm{NE}_{\mathrm{L}}$ balance postpartum.

As anticipated, cows lost BW postpartum (Figure 2, panels A and B). Despite the differences in energy balance, treatment did not affect the changes in BW in the first 6 wk of lactation (Table 6 ). Parous cows lost more BW $(P<0.001)$ than nulliparous cows (nulliparous $=$ $-0.56 \pm 0.19$ vs. parous $=-2.15 \pm 0.25 \mathrm{~kg} / \mathrm{d})$ in the first $6 \mathrm{wk}$ postpartum. Analogous to BW, cows lost body condition in the first 42 DIM, but interactions between DCAD and vitamin $\mathrm{D}(P=0.03)$ and between vitamin $\mathrm{D}$ and parity $(P=0.05)$ were detected, although differences among treatments were small. For cows fed the diet with positive DCAD, those fed PCH
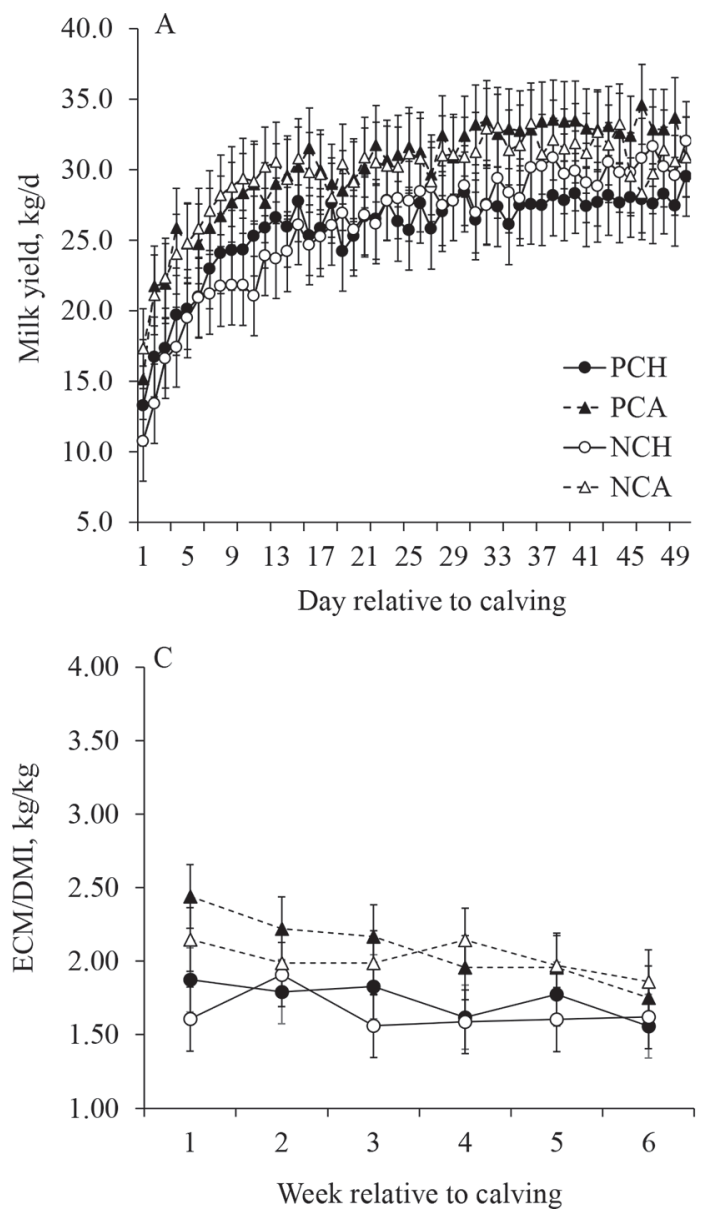

had greater BCS than cows fed PCA; however, for cows fed the diet with negative DCAD, NCA had greater BCS than NCH (Table 6). Within nulliparous cows, those fed $\mathrm{CH}$ had greater BCS than those fed CA $(\mathrm{CH}$ $=3.46$ vs. $\mathrm{CA}=3.30 \pm 0.08$ ); however, the opposite response was observed in parous cows $(\mathrm{CH}=2.95$ vs. $\mathrm{CA}=3.07 \pm 0.06)$.

\section{Blood Concentrations of Energy Metabolites Postpartum}

Plasma NEFA reached the maximum mean concentrations on the day of calving, $0.65 \pm 0.04 \mathrm{~m} M$, and then decreased constantly (effect of day, $P<0.001$ ) until the end of the first month postpartum to approximately $0.26 \pm 0.03 \mathrm{mM}$ (Figure $3 \mathrm{~A})$. An interaction $(P$
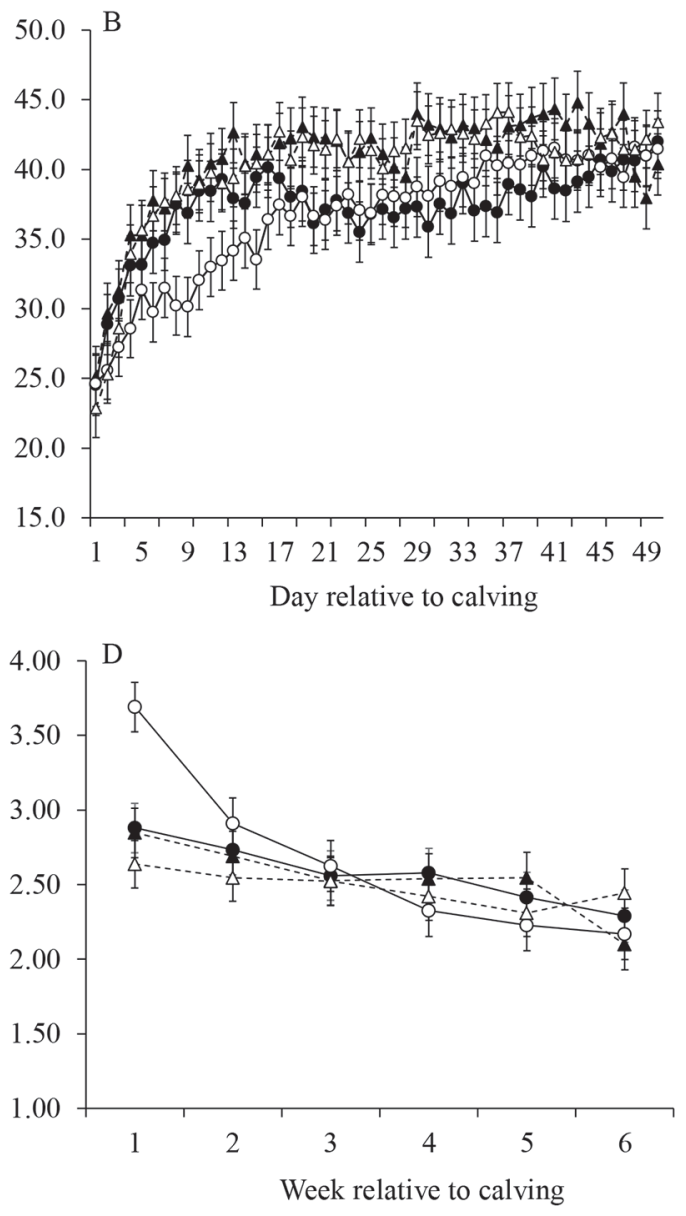

Figure 5. Milk yield in (A) nulliparous and (B) parous cows and efficiency of feed conversion into ECM in (C) nulliparous and (D) parous cows fed prepartum diets with either positive $(\mathrm{P},+130 \mathrm{mEq} / \mathrm{kg})$ or negative $(\mathrm{N},-130 \mathrm{mEq} / \mathrm{kg})$ DCAD and containing either $3 \mathrm{mg}$ of cholecalciferol ( $\mathrm{PCH}$ and $\mathrm{NCH}$, respectively) or $3 \mathrm{mg}$ of calcidiol (PCA and $\mathrm{NCA}$, respectively). Panel A: Nulliparous cow averaged (kg/d): $\mathrm{PCH}=$ $25.7 \pm 2.2 ; \mathrm{PCA}=30.2 \pm 2.2 ; \mathrm{NCH}=26.1 \pm 2.2 ; \mathrm{NCA}=29.6 \pm 2.2$. Panel B: Parous cows averaged $(\mathrm{kg} / \mathrm{d}): \mathrm{PCH}=37.3 \pm 1.7 ; \mathrm{PCA}=40.6$ $\pm 1.7 ; \mathrm{NCH}=36.6 \pm 1.6 ; \mathrm{NCA}=40.1 \pm 1.6$. Effects of parity $(P<0.001)$, interactions between DCAD and parity $(P=0.85)$, vitamin $\mathrm{D}$ and parity $(P=0.83)$, and DCAD and vitamin $\mathrm{D}$ and parity $(P=0.85)$. Panel C: Nulliparous cows averaged: $\mathrm{PCH}=1.74 \pm 0.17 ; \mathrm{PCA}=2.08 \pm$ $0.17 ; \mathrm{NCH}=1.65 \pm 0.17 ; \mathrm{NCA}=2.02 \pm 0.17$. Panel D: Parous cows averaged: $\mathrm{PCH}=2.58 \pm 0.13 ; \mathrm{PCA}=2.54 \pm 0.13 ; \mathrm{NCH}=2.66 \pm 0.13 ;$ $\mathrm{NCA}=2.48 \pm 0.12$. Effects of parity $(P<0.001)$, interactions between DCAD and parity $(P=0.68)$, vitamin D and parity $(P=0.04)$, and $\mathrm{DCAD}$ and vitamin $\mathrm{D}$ and parity $(P=0.70)$. Error bars represent SEM. 
Table 6. Effect of DCAD and source of vitamin D fed prepartum on measures of energy status in the first $42 \mathrm{~d}$ postpartum in Holstein cows ${ }^{1}$

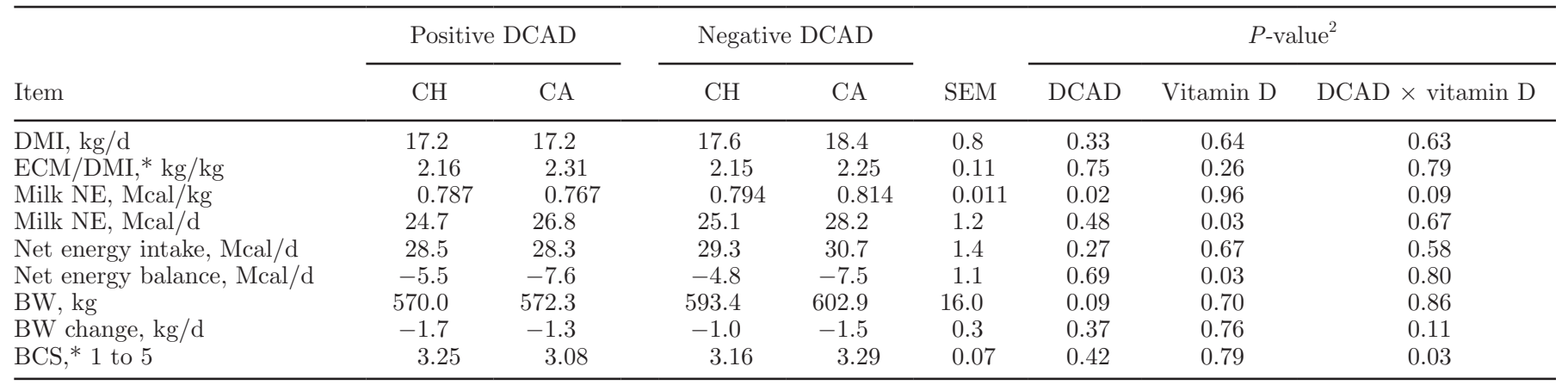

${ }^{1}$ Prepartum cows starting at $252 \mathrm{~d}$ of gestation were fed diets with either positive $(+130 \mathrm{mEq} / \mathrm{kg})$ or negative $(-130 \mathrm{mEq} / \mathrm{kg}) \mathrm{DCAD}$ and containing either $3 \mathrm{mg}$ of cholecalciferol $(\mathrm{CH})$ or $3 \mathrm{mg}$ of calcidiol (CA).

${ }^{2} \mathrm{DCAD}=$ effect of DCAD (positive vs. negative); vitamin $\mathrm{D}=$ effect of source of vitamin $\mathrm{D}(\mathrm{CH}$ vs. CA $) ; \mathrm{DCAD} \times$ vitamin $\mathrm{D}=$ interaction between DCAD and vitamin D.

*Interaction between source of vitamin $\mathrm{D}$ and parity $(P<0.05)$.

$<0.05)$ between source of vitamin $\mathrm{D}$ and parity was detected: in nulliparous cows, those supplemented with CA had greater $(P=0.04)$ NEFA concentrations than those supplemented with $\mathrm{CH}(\mathrm{CH}=0.25$ vs. $\mathrm{CA}=$ $0.33 \pm 0.03 \mathrm{mM}$ ); however, no difference was observed between source of vitamin for parous cows $(\mathrm{CH}=0.49$ vs. $\mathrm{CA}=0.48 \pm 0.03 \mathrm{mM}$ ). Dietary cation-anion difference did not affect concentrations of NEFA in plasma postpartum (Table 7).

The concentrations of BHB increased $(P<0.01)$ with the onset of lactation, and maximum values were not observed until 24 to 27 DIM (Figure 3B). An interaction $(P<0.001)$ between vitamin $\mathrm{D}$ and parity was detected because $\mathrm{BHB}$ concentrations were greater $(P<0.01)$ in nulliparous cows supplemented with CA compared with those supplemented with $\mathrm{CH}(\mathrm{CH}=$ 0.69 vs. $\mathrm{CA}=0.50 \pm 0.05 \mathrm{~m} M$, respectively), but no difference was observed in parous cows $(\mathrm{CH}=0.98$ vs. $\mathrm{CA}=1.07 \pm 0.05 \mathrm{mM}$ ). The level of DCAD did not affect postpartum BHB concentrations (Table 7).
Concentrations of cholesterol sharply increased $(P<$ 0.001 ) with DIM from 66.5 to $147.9 \pm 4.1 \mathrm{mg} / \mathrm{dL}$ (Figure $3 \mathrm{C}$ ). Dietary cation-anion difference did not affect concentrations of cholesterol, but cows fed CA tended $(P=0.09)$ to have greater concentrations than those fed $\mathrm{CH}$ (Table 7). The concentrations of total protein in serum increased $(P<0.001)$ with DIM, but there no effects of treatment (Figure 3D). The concentrations of glucose decreased $(P<0.01)$, whereas those of insulin, IGF-1, and leptin increased $(P<0.01)$ from the day of calving to 30 DIM (Figure 4, panels A-D); however, none was affected by treatment (Table 7).

\section{DISCUSSION}

The present experiment revealed that supplementing prepartum diets with $\mathrm{CA}$ in place of $\mathrm{CH}$ increased yields of colostrum and colostrum nutrients and yields of milk, $3.5 \%$ FCM, and ECM in early lactation. Although the highest DMI and production of ECM was observed in

Table 7. Effect of DCAD and source of vitamin D fed prepartum on concentrations of energy metabolites in the first $30 \mathrm{~d}$ postpartum in Holstein cows $^{1}$

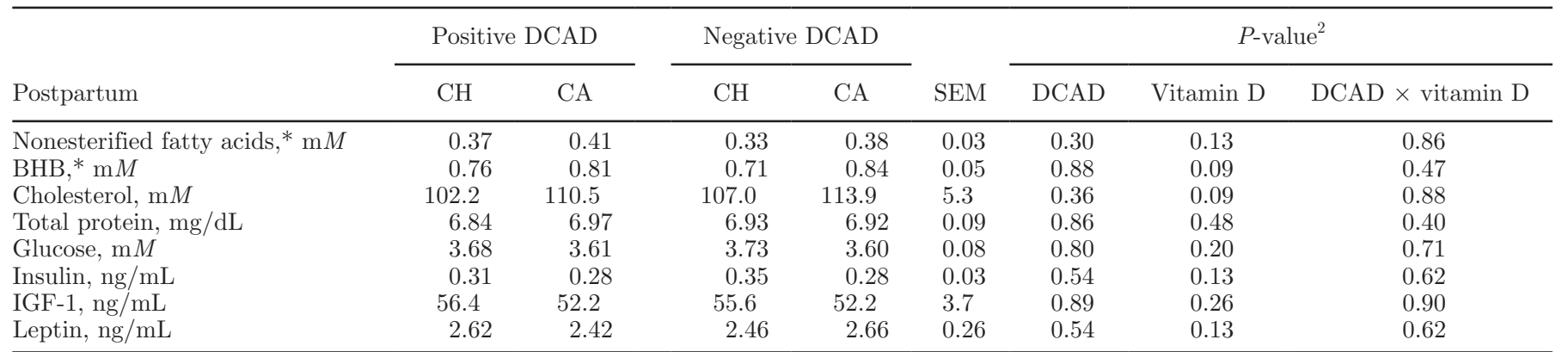

${ }^{1}$ Prepartum cows starting at $252 \mathrm{~d}$ of gestation were fed diets with either positive $(+130 \mathrm{mEq} / \mathrm{kg})$ or negative $(-130 \mathrm{mEq} / \mathrm{kg}) \mathrm{DCAD}$ and containing either $3 \mathrm{mg}$ of cholecalciferol $(\mathrm{CH})$ or $3 \mathrm{mg}$ of calcidiol $(\mathrm{CA})$. Blood sampled on d 0, 1, 2, 3, 6, 9, 12, 15, 18, 21, 24, 27, and 30 postpartum. ${ }^{2} \mathrm{DCAD}=$ effect of $\mathrm{DCAD}$ (positive vs. negative); vitamin $\mathrm{D}=$ effect of source of vitamin $\mathrm{D}(\mathrm{CH}$ vs. $\mathrm{CA}) ; \mathrm{DCAD} \times \mathrm{vitamin} \mathrm{D}=$ interaction between DCAD and vitamin D.

*Interaction between source of vitamin D and parity $(P<0.05)$. 
cows fed NCA, the increments in productive performance observed with feeding CA were detected in both the positive and negative DCAD diets. Also, feeding a diet with negative, compared with positive, DCAD in the last $3 \mathrm{wk}$ of gestation reduced DMI prepartum but only numerically increased DMI postpartum and yields of $3.5 \% \mathrm{FCM}$ and ECM.

Reducing the DCAD of the diet fed prepartum usually depresses DMI (Charbonneau et al., 2006), and cows fed the diet with $-130 \mathrm{mEq} / \mathrm{kg}$ consumed 1.0 $\mathrm{kg} / \mathrm{d}$ less DM than cows fed the diet containing +130 $\mathrm{mEq} / \mathrm{kg}$. Nevertheless, the depression in DMI observed with acidogenic diets in the current experiment was all due to a decrease in intake of $2.2 \mathrm{~kg} / \mathrm{d}$ in parous cows. Consequently, caloric intake decreased, which resulted in a less positive $\mathrm{NE}_{\mathrm{L}}$ balance prepartum. Charbonneau et al. (2006) showed that as DCAD decreased, so did DMI prepartum. Applying the same DCAD formula of Charbonneau et al. (2006) to the current diets would result in DCAD values of +181 and $-32 \mathrm{mEq} / \mathrm{kg}$ for the positive and negative DCAD diets, respectively, a shift of $212 \mathrm{mEq} / \mathrm{kg}$ of DM. Each unit of decrease in DCAD $(\mathrm{mEq} / \mathrm{kg})$ is anticipated to reduce DMI by $0.004288 \mathrm{~kg} / \mathrm{d}$ (Charbonneau et al., 2006), thus approximately $0.91 \mathrm{~kg} / \mathrm{d}$. This is similar to the observed $1.0 \mathrm{~kg} / \mathrm{d}$ depression in the current study - from 12.4 to $11.4 \mathrm{~kg} / \mathrm{d}$ - when feeding the diet with negative DCAD. However, it remains unclear why the depression was observed only in parous cows, a $2.2 \mathrm{~kg}$ difference, but not in nulliparous cows. Joyce et al. (1997) showed that addition of acidogenic salts to reduce the DCAD from +350 to $-70 \mathrm{mEq} / \mathrm{kg}$ reduced DMI of prepartum parous cows by approximately $2.0 \mathrm{~kg} / \mathrm{d}$ prepartum. On the other hand, Moore et al. (2000) found that reducing the DCAD from +150 to $-150 \mathrm{mEq} / \mathrm{kg}$ reduced DMI in nulliparous cows by $2.5 \mathrm{~kg} / \mathrm{d}$ (10.5 vs. $8.0 \mathrm{~kg} / \mathrm{d}$ ), whereas in parous cows the reduction was only numerical and of $1.5 \mathrm{~kg} / \mathrm{d}$ (14.5 to $13.0 \mathrm{~kg} / \mathrm{d}$ ). Likely, the reduction in DMI induced by acidogenic diets was caused by metabolic acidosis (Vagnoni and Oetzel, 1998), which was observed in the current experiment as reported by Rodney et al. (2018). Nevertheless, parous cows fed the diet with negative DCAD were still consuming, on average, $16.2 \mathrm{Mcal}$ of NE/d at $2 \mathrm{~d}$ before calving, and only on the day before calving did caloric intake decrease enough to result in an average negative NE balance. The effects of treatment on DMI were not observed during the postpartum period, although cows that received NCA had the highest intake of DM (no statistical effect was detected).

Parous cows fed the negative DCAD diet had greater concentrations of NEFA prepartum than those fed the positive DCAD diet. Cows fed the diet with positive DCAD had greater prepartum concentrations of glucose, insulin, and IGF-1 compared with those fed the diet with negative DCAD, and the increases in insulin and IGF-1 with the positive compared with the negative DCAD diet were more exacerbated in cows supplemented with $\mathrm{CH}$. One possible explanation for the observed differences is that cows in the positive DCAD had greater DMI prepartum and therefore had increased absorption of short-chain fatty acids, including propionate, which would stimulate hepatic uptake and gluconeogenesis, thereby increasing liver glucose output (Aschenbach et al., 2010). Increased circulating glucose stimulates insulin release by pancreatic $\beta$-cells, and insulin has been shown to recouple the growth hormone-IGF axis, thereby stimulating IGF-1 secretion (Butler et al., 2003). Exogenous insulin suppresses lipolysis in dairy cows (Sechen et al., 1989; Léonard and Block, 1997), so endogenous increases in insulin are expected to reduce NEFA concentrations, which was observed in cows fed the diet with positive DCAD.

Another possible explanation is that diet-induced metabolic acidosis reduced blood concentrations of IGF-1 (Challa et al., 1993; Brüngger et al., 1997), although results were confounded with either depression in DMI or loss of BW caused by metabolic acidosis. The effect of metabolic acidosis on insulin release is equivocal. In mice, metabolic alkalosis (blood $\mathrm{pH}=$ 7.8) reduced pancreatic insulin secretion by the perfused pancreas compared with controls (blood $\mathrm{pH}=$ 7.4). On the other hand, metabolic acidosis (blood $\mathrm{pH}=7.0)$ either increased insulin secretion under hyperglycemia $(6.6 \mathrm{mM})$ or attenuated insulin secretion under normoglycemia (3.3 m ; Rebolledo et al., 1978). In dairy cows, reducing the DCAD from +143 to -405 reduced basal insulin concentrations and attenuated insulin release in response to a glucose tolerance test, although the authors did not report DMI (Bigner et al., 1996). A reduction in DCAD from +113 to -87 $\mathrm{mEq} / \mathrm{kg}$ did not influence insulin concentrations after a glucose challenge prepartum (Grünberg et al., 2011). Collectively, it seems that with the changes in DCAD imposed in the current study, the differences in insulin and IGF-1 were likely related to the changes in DMI and not acid-base status of cows. Only under very low DCAD and exacerbated metabolic acidosis do insulin concentrations seem to change in dairy cows (Bigner et al., 1996).

The differences in glucose, insulin, and IGF-1 observed prepartum were not maintained during the postpartum period, likely because all cows were fed the same diet with a positive DCAD, and caloric intake did not differ between those fed the positive or negative DCAD prepartum. On the other hand, feeding the diet with negative DCAD improved blood $\mathrm{iCa}$ and total $\mathrm{Ca}$ concentrations at the onset of lactation (Rodney et al., 
2018) and reduced the prevalence of subclinical hypocalcemia in dairy cows (Martinez et al., 2018). In sheep, hypocalcemia reduces endogenous glucose production, particularly during a period of intense ketogenesis (Schlumbohm et al., 1997; Schlumbohm and Harmeyer, 2003). Also, subclinical hypocalcemia blunts insulin release in dairy cows (Martinez et al., 2014). Therefore, despite the reduced concentrations of glucose, insulin, and IGF-1 prepartum in cows fed the diet with negative DCAD, it is possible that, by preventing hypocalcemia, the differences observed prepartum were attenuated at the initiation of lactation and energy metabolism was improved. In fact, postpartum concentrations of energy metabolites did not differ with prepartum DCAD, which reflects the lack of differences in $\mathrm{NE}_{\mathrm{L}}$ balance, daily BW change, and BCS in those cows. Even the smaller $\mathrm{NE}_{\mathrm{L}}$ balance observed for cows fed CA compared with $\mathrm{CH}$ was not sufficient to influence concentrations of glucose, insulin, or IGF-1 postpartum.

Lactation performance was only numerically influenced by prepartum DCAD. Cows fed the diet with negative DCAD produced $1.1 \mathrm{~kg}$ more ECM than cows fed the positive DCAD diet. Lean et al. (2014) reviewed the literature on altering the DCAD in diets fed to prepartum cows and observed an increase in production of $1.15 \mathrm{~kg} / \mathrm{d}$ for the first 65 DIM by reducing the DCAD. Nevertheless, those authors identified only a limited number of experiments that used nulliparous cows and responses were heterogeneous, but feeding diets with negative DCAD to nulliparous cows resulted in a mean depression in production of $1.48 \mathrm{~kg} / \mathrm{d}$. In the present experiment, no interaction between DCAD and parity was detected, and the same numerical increases in ECM were observed with the negative DCAD diet in nulliparous $(1.0 \mathrm{~kg} / \mathrm{d})$ and parous cows $(1.2 \mathrm{~kg} / \mathrm{d})$. Using the mean milk response to feeding acidogenic diets prepartum of $1.15 \mathrm{~kg} / \mathrm{d}$ (Lean et al., 2014), a much larger experiment would be needed with transition cows to accommodate the intrinsic variability in production in early lactation to detect statistical effects caused by the negative DCAD. Nevertheless, the responses observed are within the expected changes to manipulating the prepartum DCAD (Lean et al., 2014).

Feeding CA tended to improve yield of colostrum and improved concentrations and yields of $\mathrm{N}$ fractions in colostrum such as true protein, IgG, and urea N. These changes resulted in increased yields of TS in colostrum compared with cows fed CH. Similar to colostrum yield, feeding CA improved yields of milk, 3.5\% FCM, and ECM, and tended to improve yields of fat and true protein in the first 49 DIM. One of the benefits of feeding $\mathrm{CA}$ in the present experiment was that it reduced morbidity in dairy cows (Martinez et al., 2018), and pe- ripartum diseases are known to have devastating effects on lactation performance, with the greater depression in yields of milk and ECM being observed in the first weeks relative to the diagnosis of disease (Østergaard and Gröhn, 1999). When additional statistical analyses were performed in the current experiment, including morbidity reported by Martinez et al. (2018) in the models for postpartum DMI and production of ECM, it was clear that cows that developed clinical diseases in early lactation consumed $2.7 \mathrm{~kg} / \mathrm{d}$ less $\mathrm{DM}$ and produced $6.3 \mathrm{~kg} / \mathrm{d}$ less ECM during the experiment. Therefore, the reduction in morbidity observed in cows fed CA (Martinez et al., 2018) likely explains some of the improvements in production performance.

Nevertheless, because most diseases occur in the days following calving, it is less logical that they would influence colostrum yield and composition. Therefore, in addition to the reduction in diseases, we could hypothesize that CA might have had direct effects on mammary cells. Activation of vitamin D requires 2 sequential hydroxylations, with the second hydroxylation primarily taking place in the kidney and carried out by CYP27B1, also known as $1 \alpha$-hydroxylase (Horst et al., 1994). Recent research shows that the conversion of 25-hydroxyvitamin $\mathrm{D}_{3}$ into 1,25 -dihydroxyvitamin $\mathrm{D}_{3}$ also takes place in cell tissues other than kidney. For instance, human mammary epithelial cells locally express CYP27B1; therefore, they are capable of synthesizing 1,25-dihydroxyvitamin $\mathrm{D}_{3}$ from 25-hydroxyvitamin $\mathrm{D}_{3}$ (Kemmis et al., 2006). Mammary epithelial cells also express the vitamin D receptor (VDR). Expression of $C Y P 27 B 1$ and $V D R$ increased in the murine mammary gland during pregnancy, and maximum $V D R$ expression in the mammary gland was observed during lactation (Zinser and Welsh, 2004), suggesting that local synthesis of 1,25-dihydroxyvitamin $\mathrm{D}_{3}$ contributes to mammary development. Furthermore, VDR knockout mice exhibited impaired mammary development during pregnancy, although milk yield was not affected (Zinser and Welsh, 2004). Activation of VDR by 1,25-hydroxyvitamin $\mathrm{D}_{3}$ has been shown to trigger extensive genomic changes in epithelial cells (Beaudin et al., 2015) and, in general, is known to contribute to control of proliferation and differentiation of mammary epithelial cells (Welsh, 2007). Although most data on the role of vitamin $\mathrm{D}$ on mammary cell biology have been related to tumorigenesis, we could speculate physiological roles during preparation for a new lactation when there is a decrease in the rate of epithelial cell death relative to epithelial cell proliferation (Sorensen et al., 2006). Bovine mammary epithelial cells are very sensitive to 1,25-dihydroxyvitamin $\mathrm{D}_{3}$ in culture (Merriman et al., 2015), and increased synthesis in mammary tissue be- 
cause of increased substrate availability, combined with increased calcium prepartum, in cows fed CA might have contributed to increased colostrum and milk yield.

25-Hydroxyvitamin $\mathrm{D}_{3}$ has a long half-life in circulation, approximately $15 \mathrm{~d}$, compared with only 2 to $3 \mathrm{~d}$ for vitamin $\mathrm{D}_{3}$ (Jones, 2008), which may prolong the effects of CA into the postpartum period, after cessation of supplementation. Indeed, elevated concentrations of 25-hydroxyvitamin $\mathrm{D}_{3}$ in plasma of dairy cows supplemented with CA prepartum extended at least up to 30 DIM compared with cows supplemented with CH (Rodney et al., 2018). Continuous autocrine and paracrine effects of mammary-produced 1,25-dihydroxyvitamin $\mathrm{D}_{3}$ might have influenced mammary cell proliferation and activity in early lactation in cows supplemented with CA prepartum. Also, 1,25-dihydroxyvitamin $\mathrm{D}_{3}$ stimulates synthesis and secretion of prolactin from pituitary, decidua, and even from immune cells in rats, and from human endometrium (Delvin et al., 1990; Díaz et al., 2011). Although prolactin is not critical for milk production in dairy cattle, it has permissive effects for steroids, and a surge in prolactin occurs hours before parturition (Ingalls et al., 1973), which has been demonstrated to be critical for subsequent milk yield (Akers et al., 1981). Perhaps, cows fed CA had changes in prolactin secretion induced by 1,25-dihydroxyvitamin $\mathrm{D}_{3}$ that might have benefited milk production. Also, 1,25-dihydroxyvitamin $\mathrm{D}_{3}$ might increase the expression of $R A N K L$, which is considered an important paracrine mediator of progesterone induced-proliferation during alveologenesis (Macias and Hinck, 2012). Collectively, the improved production of milk observed in cows supplemented with CA might have been the result of reduced morbidity combined with potential paracrine and autocrine effects on mammary cells during the periparturient period.

Feeding CA increased prepartum concentrations of 1,25-dihydroxyvitamin $\mathrm{D}_{3}$ prepartum in plasma of dairy cows (Rodney et al., 2018), and CA improved colostrum yield and yields of components in colostrum, particularly the protein fractions. Indeed, an interesting finding of the present experiment was that supplementation with CA increased concentrations of $\operatorname{IgG}$ in colostrum. Among the many functions of 1,25-dihydroxyvitamin $\mathrm{D}_{3}$ is the modulation of innate and adaptive immune responses. Calcitriol binds to VDR and recognizes cognate DNA motifs called vitamin D response elements in the nucleus of the cell, with high affinity inducing different responses (White, 2011). For instance, in activated human B cells, 25-hydroxyvitamin $\mathrm{D}_{3}$ and 1,25-dihydroxyvitamin $\mathrm{D}_{3}$ increased IL10 production 3 -fold (Heine et al., 2008), and IL-10 can promote B-cell differentiation into plasmablasts to secrete immunoglobulin (Defrance et al., 1992).
Reinhardt et al. (1999) reported that administration of 1,25-dihydroxyvitamin $\mathrm{D}_{3}$ to cows at the time of vaccination with Escherichia coli increased $\operatorname{IgG}_{1}$ antibody titers, suggesting an improved humoral immune response. Perhaps, cows fed CA had increased serum concentrations of IgG during late gestation, concurrent with vaccinations that took place prepartum, which increased the availability of these proteins for uptake by mammary cells and transferred into colostrum. Also, it is known that 1,25-dihydroxyvitamin $\mathrm{D}_{3}$ improves calcium uptake by mammary cells (Mezzetti et al., 1988; Sun et al., 2016), and Rodney et al. (2018) showed that cows fed CA had increased concentration and secretion of calcium in colostrum. The increased flux of calcium into the mammary gland to be secreted in colostrum might involve an increased amount of casein, which eventually results in larger amounts of proteins secreted in milk. In goat mammary cells, 1,25-dihydroxyvitamin $\mathrm{D}_{3}$ stimulates calcium and glucose uptakes because of stimulation of cell proliferation and expression of $V D R$ and genes involved in calcium uptake and transport and genes for glucose transporters (Sun et al., 2016). Therefore, the positive effects of increased concentrations of 25-hydroxyvitamin $\mathrm{D}_{3}$ and 1,25-dihydroxyvitamin $\mathrm{D}_{3}$ observed in cows fed CA might have stimulated mammary epithelial cell function, as discussed previously. Nevertheless, we are unaware of a specific role of vitamin $\mathrm{D}$ on transport and incorporation of proteins in bovine milk. In mice, vitamin $\mathrm{D}$ deficiency attenuates milk protein synthesis (Bhattacharjee et al., 1987), and those authors suggested that, although vitamin D was not critical for morphological development of the mammary gland in mice, it was required for normal function and protein secretion.

\section{CONCLUSIONS}

Feeding a diet with a DCAD of $-130 \mathrm{mEq} / \mathrm{kg}$ of DM during the last $21 \mathrm{~d}$ of gestation reduced DMI prepartum only in parous cows. The reduced DMI prepartum in cows fed the diet with negative DCAD resulted in reduced concentrations of glucose, insulin, and IGF-1 in plasma prepartum. Nevertheless, cows fed the negative DCAD remained in positive energy balance until $2 \mathrm{~d}$ before calving. Cows fed the negative DCAD produced numerically more ECM $(1.1 \mathrm{~kg} / \mathrm{d})$, which is in line with responses reported in the literature. Feeding CA in place of $\mathrm{CH}$ prepartum at $3 \mathrm{mg} / \mathrm{d}$ improved yields of colostrum, milk, $3.5 \%$ FCM, and ECM with a numerical increase in DMI. Colostrum protein output, including $\mathrm{IgG}$, was enhanced by CA. Because of the increased production, cows fed CA were under more negative $\mathrm{NE}$ balance, although changes in BW and BCS did not differ among treatments. The greatest yields of $3.5 \%$ 
FCM and ECM were observed in cows fed the negative DCAD diet combined with CA. Improvements in production in cows fed CA were attributed to differences in morbidity, although the changes in colostrum yield and composition lead us to speculate that increases in 25-hydroxyvitamin $\mathrm{D}_{3}$ in plasma pre- and postpartum in cows fed CA might have influenced mammary biology. Further studies are warranted to investigate the underlying mechanism by which CA supplementation influences production in dairy cows.

\section{ACKNOWLEDGMENTS}

The authors thank Rafael S. Bisinotto, André L. G. Dias, José Freitas, Gabriel C. Gomes, Leandro F. Greco, Camilo Lopera, Kathryn Merriman, Kaitlin M. O'Connor, Adele Pietras, Guilherme C. S. Pontes, Eduardo S. Ribeiro, Rosiane Sales, Ricarda M. Santos, Johnathan Smith, Marcos Zenobi, and Matthew Wadford from the University of Florida (Gainesville) for their help with the conduct of the experiment; and Sergei Sennikov (University of Florida, Gainesville) for assistance with the analysis of samples; and Rick Morse from Milk Market Administrator Laboratory (Atlanta, GA) for his collaboration in processing the colostrum and milk samples. Financial support was provided by Arm \& Hammer Animal Nutrition (Princeton, NJ), DSM Nutritional Products (Kaiseraugst, Switzerland), and Dairy Australia (Southbank, Australia).

\section{REFERENCES}

Akers, R. M., D. E. Bauman, A. V. Capuco, G. T. Goodman, and H. A. Tucker. 1981. Prolactin regulation of milk secretion and biochemical differentiation of mammary epithelial cells in periparturient cows. Endocrinology 109:23-30.

Aschenbach, J. R., N. B. Kristensen, S. S. Donkin, H. M. Hammon, and G. B. Penner. 2010. Gluconeogenesis in dairy cows: The secret of making sweet milk from sour dough. Life 62:869-877.

Beaudin, S. G., S. Robilotto, and J. Welsh. 2015. Comparative regulation of gene expression by 1,25-dihydroxyvitamin D3 in cells derived from normal mammary tissue and breast cancer. J. Steroid Biochem. Mol. Biol. 148:96-102.

Bhattacharjee, M., S. Wientroub, and B. K. Vonderhaar. 1987. Milk protein synthesis by mammary glands of vitamin D-deficient mice. Endocrinology 121:865-874.

Bigner, D. R., J. P. Goff, M. A. Faust, J. L. Burton, H. D. Tyler, and R. L. Horst. 1996. Acidosis effects on insulin response during glucose tolerance tests in Jersey cows. J. Dairy Sci. 79:2182-2188.

Block, E. 1984. Manipulating dietary anions and cations for prepartum dairy cows to reduce incidence of milk fever. J. Dairy Sci. 67:2939-2948.

Box, G. E. P., and D. R. Cox. 1964. An analysis of transformations. J. R. Stat. Soc. B 26:211-252.

Brüngger, M., H. N. Hulter, and R. Krapf. 1997. Effect of chronic metabolic acidosis on thyroid hormone homeostasis in humans. Am. J. Physiol. 272:F648-F653.

Butler, S. T., A. L. Marr, S. H. Pelton, R. P. Radcliff, M. C. Lucy, and W. R. Butler. 2003. Insulin restores GH responsiveness dur- ing lactation-induced negative energy balance in dairy cattle: effects on expression of IGF-I and GH receptor 1A. J. Endocrinol. 176:205-217.

Challa, A., W. Chan, R. J. Krieg, M. A. Thabet, F. Liu, R. L. Hintz, and J. C. Chan. 1993. Effect of metabolic acidosis on the expression of insulin-like growth factor and growth hormone receptor. Kidney Int. 44:1224-1227.

Chamberlin, W. G., J. R. Middleton, J. N. Spain, G. C. Johnson, M. R. Ellersieck, and P. Pithua. 2013. Subclinical hypocalcemia, plasma biochemical parameters, lipid metabolism, postpartum disease, and fertility in postparturient dairy cows. J. Dairy Sci. 96:7001-7013.

Chapinal, N., M. E. Carson, S. J. LeBlanc, K. E. Leslie, S. Godden, M. Capel, J. E. P. Santos, M. W. Overton, and T. F. Duffield. 2012. The association of serum metabolites in the transition period with milk production and early-lactation reproductive performance. J. Dairy Sci. 95:1301-1309.

Charbonneau, E., D. Pellerin, and G. R. Oetzel. 2006. Impact of lowering dietary cation-anion difference in nonlactating dairy cows: a meta-analysis. J. Dairy Sci. 89:537-548.

Curtis, C. R., H. N. Erb, C. J. Sniffen, R. D. Smith, P. A. Powers, M. C. Smith, M. E. White, R. B. Hillman, and E. J. Pearson. 1983. Association of parturient hypocalcemia with eight periparturient disorders in Holstein cows. J. Am. Vet. Med. Assoc. 183:559-561.

Defrance, T., B. Vanbervliet, F. Brière, I. Durand, F. Rousset, and J. Banchereau. 1992. Interleukin 10 and transforming growth factor beta cooperate to induce anti-CD40-activated naive human B cells to secrete immunoglobulin A. J. Exp. Med. 175:671-682.

Delvin, E. E., L. Gagnon, A. Arabian, and W. Gibb. 1990. Influence of calcitriol on prolactin and prostaglandin production by human decidua. Mol. Cell. Endocrinol. 71:177-183.

Díaz, L., I. Martínez-Reza, R. García-Becerra, L. González, F. Larrea, and I. Méndez. 2011. Calcitriol stimulates prolactin expression in non-activated human peripheral blood mononuclear cells: Breaking paradigms. Cytokine 55:188-194.

Elanco Animal Health. 2009. The 5-point body condition scoring system. Bulletin AI 10752. Elanco Animal Health, Greenfield, IN.

Ender, F., I. W. Dishington, and A. Helgebostad. 1971. Calcium balance studies in dairy cows under experimental induction or prevention of hypocalcaemia paresis puerperalis. Z. Tierphysiol. Tierernahr. Futtermittelkd. 28:233-256.

Ferguson, J. D., D. T. Galligan, and N. Thomsen. 1994. Principal descriptors of body condition score in Holstein cows. J. Dairy Sci. 77:2695-2703.

Gochman, N., and J. M. Schmitz. 1972. Application of a new peroxide indicator reaction to the specific, automated determination of glucose with glucose oxidase. Clin. Chem. 18:943-950.

Grünberg, W., S. S. Donkin, and P. D. Constable. 2011. Periparturient effects of feeding a low dietary cation-anion difference diet on acidbase, calcium, and phosphorus homeostasis and on intravenous glucose tolerance test in high-producing dairy cows. J. Dairy Sci. 94:727-745.

Heine, G., U. Niesner, H. D. Chang, A. Steinmeyer, U. Zuguel, T. Zuberbier, A. Radbruch, and M. Worm. 2008. 1,25-Dihydroxyvitamin $\mathrm{D}_{3}$ promotes IL-10 production in human B cells. Eur. J. Immunol. 38:2210-2218.

Horst, R. L., J. P. Goff, and T. A. Reinhardt. 1994. Calcium and vitamin D metabolism in the dairy cow. J. Dairy Sci. 77:1936-1951.

Ingalls, W. G., E. M. Convey, and H. D. Hafs. 1973. Bovine serum LH, $\mathrm{GH}$, and prolactin during late pregnancy, parturition and early lactation. Proc. Soc. Exp. Biol. Med. 143:161-164.

Johnson, M. M., and J. P. Peters. 1993. Technical note: An improved method to quantify nonesterified fatty acids in bovine plasma. J. Anim. Sci. 71:753-756.

Jones, G. 2008. Pharmokinetics of vitamin D toxicity. Am. J. Clin. Nutr. 88:582S-586S.

Jørgensen, E., and A. R. Pedersen. 1998. How to obtain those nasty standard errors from transformed data - and why they should not be used. Biometry Research Unit-Internal report 7. Danish Institute of Agricultural Sciences, Tjele, Denmark. 
Joyce, P. W., W. K. Sanchez, and J. P. Goff. 1997. Effect of anionic salts in prepartum diets based on alfalfa. J. Dairy Sci. 80:28662875 .

Kehrli, M. E. Jr., and J. P. Goff. 1989. Periparturient hypocalcemia in cows: Effects on peripheral blood neutrophil and lymphocyte function. J. Dairy Sci. 72:1188-1196.

Kemmis, C. M., S. M. Salvador, K. M. Smith, and J. Welsh. 2006. Human mammary epithelial cells express CYP27B1 and are growth inhibited by 25-hydroxyvitamin D-3, the major circulating form of vitamin D-3. J. Nutr. 136:887-892.

Lean, I. J., P. J. DeGaris, P. Celi, D. M. McNeill, R. M. Rodney, and D. R. Fraser. 2014. Influencing the future: Interactions of skeleton, energy, protein and calcium during late gestation and early lactation. Anim. Prod. Sci. 54:1177-1189.

Léonard, M., and E. Block. 1997. Effects on nutrient and hormonal profile of long-term infusions of glucose or insulin plus glucose in cows treated with recombinant bovine somatotropin before peak milk yield. J. Dairy Sci. 80:127-143.

Liu, S., W. Tang, J. Zhou, J. R. Stubbs, Q. Luo, M. Pi, and L. D. Quarles. 2006. Fibroblast growth factor 23 is a counter-regulatory phosphaturic hormone for vitamin D. J. Am. Soc. Nephrol. $17: 1305-1315$

Macias, H., and L. Hinck. 2012. Mammary gland development. Wiley Interdiscip. Rev. Dev. Biol. 1:533-557.

Martinez, N., C. A. Risco, F. S. Lima, R. S. Bisinotto, L. F. Greco, E. S. Ribeiro, F. Maunsell, K. Galvão, and J. E. P. Santos. 2012 Evaluation of peripartal calcium status, energetic profile, and neutrophil function in dairy cows at low or high risk of developing uterine disease. J. Dairy Sci. 95:7158-7172.

Martinez, N., R. M. Rodney, E. Block, L. L. Fernandez, C. D. Nelson, I. J. Lean, and J. E. P. Santos. 2018. Effects of prepartum dietary cation-anion difference and source of vitamin D in dairy cows: Health and reproductive responses. J. Dairy Sci. 101:2563-2578. https://doi.org/10.3168/jds.2017-13740.

Martinez, N., L. D. P. Sinedino, R. S. Bisinotto, R. Daetz, C. Lopera C. A. Risco, K. N. Galvão, W. W. Thatcher, and J. E. P. Santos. 2016. Effects of oral calcium supplementation on mineral and acidbase status, energy metabolites, and health of postpartum dairy cows. J. Dairy Sci. 99:8397-8416.

Martinez, N., L. D. P. Sinedino, R. S. Bisinotto, E. S. Ribeiro, G. C. Gomes, F. S. Lima, L. F. Greco, C. A. Risco, K. N. Galvão, D. Taylor-Rodriguez, J. P. Driver, W. W. Thatcher, and J. E. P. Santos. 2014. Effect of induced subclinical hypocalcemia on physiological responses and neutrophil function in dairy cows. J. Dairy Sci. 97:874-887.

Merriman, K. E., M. F. Kweh, J. L. Powell, J. D. Lippolis, and C. D. Nelson. 2015. Multiple $\beta$-defensin genes are upregulated by the vitamin D pathway in cattle. J. Steroid Biochem. Mol. Biol. 154:120-129.

Mezzetti, G., M. Monti, L. Casolo, G. Piccinini, and M. Moruzzi. 1988. 1,25-Dihydroxycholecalciferol-dependent calcium uptake by mouse mammary gland in culture. Endocrinology 122:389-394.

Moore, S. J., M. J. VandeHaar, B. K. Sharma, T. E. Pilbeam, D. K. Beede, H. F. Bucholtz, J. S. Liesman, R. L. Horst, and J. P. Goff. 2000. Effects of altering dietary cation-anion difference on calcium and energy metabolism in peripartum cows. J. Dairy Sci. 83:2095-2104

NRC. 2001. Nutrient Requirements of Dairy Cattle. 7th rev. ed. Natl Acad. Press, Washington, DC.

Østergaard, S., and Y. T. Gröhn. 1999. Effects of diseases on test day milk yield and body weight of dairy cows from Danish research herds. J. Dairy Sci. 82:1188-1201.

Rebolledo, O. R., R. E. Hernandez, A. C. Zanetta, and J. J. Gagliardino. 1978. Insulin secretion during acid-base alterations. Am. J. Physiol. 234:E426-E429.
Reinhardt, T. A., J. D. Lippolis, B. J. McCluskey, J. P. Goff, and R. L. Horst. 2011. Prevalence of subclinical hypocalcemia in dairy herds. Vet. J. 188:122-124.

Reinhardt, T. A., J. R. Stabel, and J. P. Goff. 1999. 1,25-Dihydroxyvitamin D3 enhances milk antibody titers to Escherichia coli J5 vaccine. J. Dairy Sci. 82:1904-1909.

Rodney, R. M., N. Martinez, E. Block, L. L. Fernandez, P. Celi, C. D. Nelson, J. E. P. Santos, and I. J. Lean. 2018. Effects of prepartum dietary cation-anion difference and source of vitamin D in dairy cows: Vitamin D, mineral and bone metabolism. J. Dairy Sci. 101:2519-2543. https://doi.org/10.3168/jds.2017-13737.

Schlumbohm, C., and J. Harmeyer. 2003. Hypocalcemia reduces endogenous glucose production in hyperketonemic sheep. J. Dairy Sci. 86:1953-1962.

Schlumbohm, C., H. P. Sporleder, H. Gürtler, and J. Harmeyer. 1997. Effect of insulin on glucose and fat metabolism in ewes during various reproductive states in normal and hypocalcemia. Dtsch. Tierarztl. Wochenschr. 104:359-365.

Sechen, S. J., S. N. McCutcheon, and D. E. Bauman. 1989. Response to metabolic challenges in early lactation dairy cows during treatment with bovine somatotropin. Domest. Anim. Endocrinol. 6:141-154.

Seifi, H. A., S. J. LeBlanc, K. E. Leslie, and T. F. Duffield. 2011. Metabolic predictors of post-partum disease and culling risk in dairy cattle. Vet. J. 188:216-220.

Sorensen, M. T., J. V. Nørgaard, P. K. Theil, M. Vestergaard, and K. Sejrsen. 2006. Cell turnover and activity in mammary tissue during lactation and the dry period in dairy cows. J. Dairy Sci. 89:4632-4639.

Sukhija, P. S., and D. L. Palmquist. 1988. Rapid method for determination of total fatty acid content and composition of feedstuffs and feces. J. Agric. Food Chem. 36:1202-1206.

Sun, F., Y. Cao, C. Yu, X. Wei, and J. Yao. 2016. 1,25-Dihydroxyvitamin $\mathrm{D}_{3}$ modulates calcium transport in goat mammary epithelial cells in a dose- and energy dependent manner. J. Anim. Sci. Biotechnol. 7:41.

Vagnoni, D. B., and G. R. Oetzel. 1998. Effects of dietary cationanion difference on the acid-base status of dry cows. J. Dairy Sci. 81:1643-1652

Van Soest, P. J., J. B. Robertson, and B. A. Lewis. 1991. Methods for dietary fiber, neutral detergent fiber and nonstarch polysaccharides in relation to animal nutrition. J. Dairy Sci. 74:3583-3597.

Vidal, B. C. Jr., K. D. Rausch, M. E. Tumbleson, and V. Singh. 2009 Determining corn germ and pericarp residual starch by acid hydrolysis. Cereal Chem. 86:133-135.

Weiss, W. P., E. Azem, W. Steinberg, and T. A. Reinhardt. 2015. Effect of feeding 25-hydroxyvitamin $\mathrm{D}_{3}$ with a negative cation-anion difference diet on calcium and vitamin $\mathrm{D}$ status of periparturient cows and their calves. J. Dairy Sci. 98:5588-5600.

Welsh, J. 2007. Targets of vitamin D receptor signaling in the mammary gland. J. Bone Miner. Res. 22(Suppl. 2):V86-V90.

White, J. H. 2011. Vitamin D innate immunity. Pages $1777-1784$ in Vitamin D. Vol. 1. 3rd ed. J. Feldman, W. Pike and J. S. Adams, ed. Elsevier, Philadelphia, PA.

Wilkens, M. R., I. Oberheide, B. Schröder, E. Azem, W. Steinberg, and G. Breves. 2012. Influence of the combination of 25-hydroxyvitamin D3 and a diet negative in cation-anion difference on peripartal calcium homeostasis of dairy cows. J. Dairy Sci. 95:151-164

Yoshida, T., N. Yoshida, T. Monkawa, M. Hayashi, and T. Saruta 2001. Dietary phosphorus deprivation induces 25-hydroxyvitamin $\mathrm{D}_{3}$ 1alpha-hydroxylase gene expression. Endocrinology 142:17201726

Zinser, G. M., and J. Welsh. 2004. Accelerated mammary gland development during pregnancy and delayed postlactational involution in vitamin $\mathrm{D}_{3}$ receptor null mice. Mol. Endocrinol. 18:2208-2223. 